\title{
The blueschist-associated perovskite-andradite-bearing serpentinized harzburgite from Dobšiná (the Meliata Unit), Slovakia
}

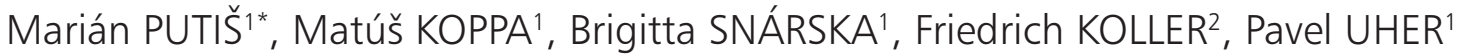 \\ ${ }^{1}$ Department of Mineralogy and Petrology, Faculty of Natural Sciences, Comenius University, Mlynská dolina G, 84215 Bratislava, \\ Slovakia;putis@fns.uniba.sk \\ ${ }^{2}$ Department of Lithospheric Research, University of Vienna, Althanstr. 14, Vienna, Austria \\ * Corresponding author
}

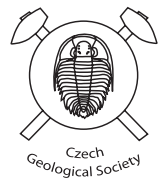

\begin{abstract}
Unique, perovskite(Prv)-andradite(Adr)-bearing serpentinized harzburgite fragments occur in Late Jurassic-Early Cretaceous subduction-accretionary wedge complex of the Meliata tectonic Unit (Slovakia, Western Carpathians). These rocks reflect magmatic (E1) and partial melting (E2) mantle events followed by metamorphic blueschist-facies (E3) and fluid-rock interaction (E4) events accompanied by crystallization of Prv and/or Adr. The incompletely solidified slightly depleted (residual) harzburgite composed of early-magmatic assemblage of $\mathrm{Ol}, \mathrm{Opx}_{1}, \mathrm{Cr}-\mathrm{Spl} \pm \mathrm{Cpx}_{1}$ (E1 event) underwent partial melting (E2 event) under subsolidus mantle conditions. The late-magmatic aggregates of $\mathrm{Cpx}_{2}$, $\mathrm{Cr}-\mathrm{Spl}$, scarce $\mathrm{Opx}_{2}$, due to this batch melting, occur around the $\mathrm{Opx}_{1}\left( \pm \mathrm{Cpx}_{1}\right)$ porphyroclasts. The fractures and cleavage planes of the kinked $\mathrm{Opx}$, porphyroclasts are filled by $\mathrm{Cpx}_{3}$ as a result of subsolidus recrystallization of the $\mathrm{Opx}_{1}$. Cloudy lower $\mathrm{Al} \mathrm{Cpx}_{4}$ associated with pargasite in reaction rims between the $\mathrm{Opx}_{1}$ and $\mathrm{Cpx}_{2}$, or antigorite replacing $\mathrm{Ol}$, could represent the $\mathrm{E} 3$ high-pressure metamorphic event (dated at 160 to $150 \mathrm{Ma}$, according to published ${ }^{40} \mathrm{Ar}-{ }^{39} \mathrm{Ar}$ data for "phengitic" white mica from blueschists) in serpentinites. Serpentinized zones of harzburgite contain Prv, which occurs in serpentinized Opx porphyroclasts. Orthopyroxene (Opx $)$ breakdown and formation of Prv, (Ti-rich) Adr and chrysotile appears to be postdating the closure of the Meliata back-arc basin (c. 200 to $160 \mathrm{Ma}$ ) and HP metamorphism. Perovskite genesis can therefore be bound to the exhumation-related serpentinization in subduction channel and emplacement of serpentinites into subduction-accretionary wedge (E4 event at $300-500^{\circ} \mathrm{C} / 5-15 \mathrm{kbar}$, at 150 to $130 \mathrm{Ma}$ ?). The bulk-rock trace-element patterns suggest enrichment in LREE, $\mathrm{Ba}, \mathrm{Cs}, \mathrm{U}, \mathrm{Pb}, \mathrm{Sb}$ and $\mathrm{Li}$ in comparison with HREE, HFSE, Rb and Sr. Such element mobility indicates fluid-rock interaction. Pervading aqueous fluids rich in $\mathrm{CO}_{2}$ were transporting $\mathrm{Ca}$, $\mathrm{Ti}$, Fe, LREE partitioned into Prv grown along the Cpx exsolution lamellae in Opx . The sources of such fluids might have been the blueschist- to greenschist-facies rocks from the Meliata mélange type subduction-accretionary wedge. The late-metamorphic $\mathrm{H}_{2} \mathrm{O}-\mathrm{CO}_{2} / \mathrm{Si}-\mathrm{Fe}-\mathrm{Mn}$-rich fluids caused partial replacement of Prv by pyrophanite and crystallization of (Ti-rich) Adr at the expense of Cpx and Prv.
\end{abstract}

Keywords: harzburgite, blueschist, perovskite, andradite, fluid-rock interaction, Meliata Back-arc Basin Received: 22 July 2012; accepted: 23 December 2012; handling editor: E. Jelinek

The online version of this article (http://dx.doi.org/10.3190/jgeosci.128) contains supplementary electronic material.

\section{Introduction}

Perovskite (Prv) typically occurs in $\mathrm{SiO}_{2}$-undersaturated magmatic (Currie 1975; Chakhmouradian and Mitchell 1997, 2000; Mitchell and Chakhmouradian 1998; Heaman et al. 2003) or high-temperature contact-metamorphic rocks (Marincea et al. 2010; Uher et al. 2011). Perovskite was however also found from medium- to low-temperature reaction domains between the chemically contrasting rocks metamorphosed in blueschist to eclogite facies, as reported further. Alteration and reaction-metasomatic zones in ultramafics are reliable indicators of fluid-rock interaction processes (Grégoire et al. 2001; Scambelluri et al. 2004, 2006; Khedr and Arai 2009; Kodolányi et al. 2012; Uysal et al. 2012). For example, abyssal peridotites are generally strongly affected by oceanic (seafloor) hydrothermal alterations like serpentinization (Bodinier and Godard 2007). Remarkable is the presence of Prv in the Alpine blueschist- to eclogite-facies metaophiolite units of northern Corsica (Malvoisin et al. 2012). There, the contact between a serpentinite body and a siliceous marble represents a rodingite-type reaction zone with a centimetre-thick selvage composed of diopside-andradite and/or grossular-perovskite on the serpentinite side. Müntener and Hermann (1994) found Ti-rich Adr in an assemblage of diopside, clinochlore and magnetite with rare ilmenite and perovskite from the peak metamorphic assemblage $\left(400-450^{\circ} \mathrm{C}, 5 \pm 2 \mathrm{kbar}\right)$ of a metapyroxenite from Malenco, Italy. The hydrothermal crystallization of Ti-rich Adr in veins demonstrates there the Ti mobility in aqueous fluids under moderate $\mathrm{P}-\mathrm{T}$ conditions. Medium- to low-temperature mobility of Ti, $\mathrm{Zr}$ and REE in 


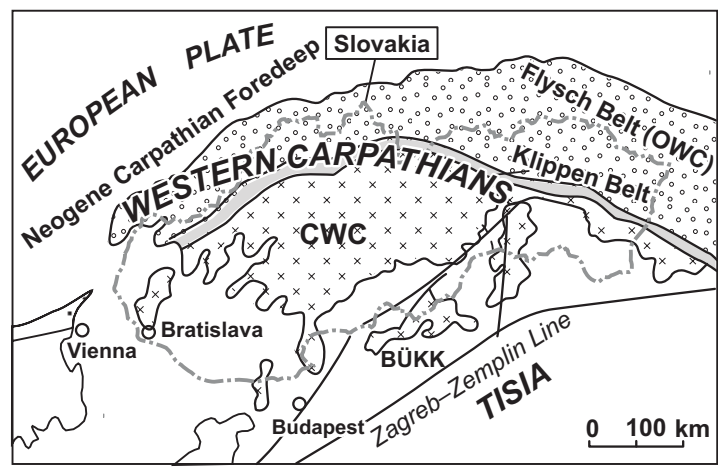

$\because \therefore \therefore \therefore \therefore$ Cretaceous-Palaeogene sediments of the Outer Flysch Belt

$\times \times \times \times$ Basement and Upper Palaeozoic to Tertiary cover complexes

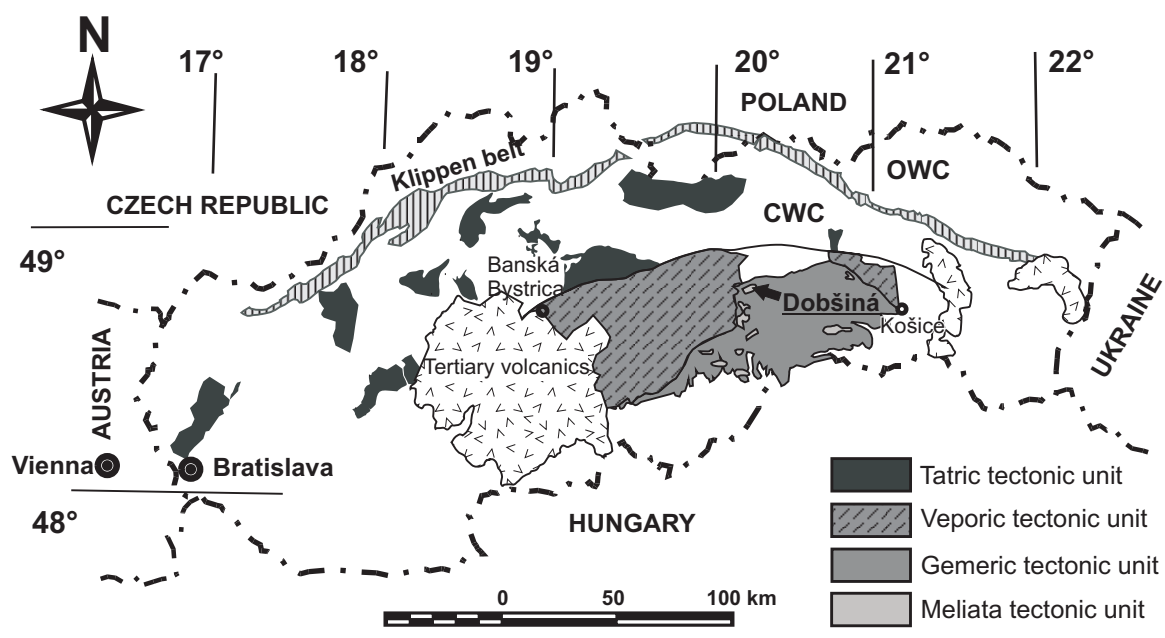

Fig. 1 Geological-tectonic sketch map of the Western Carpathians. OWC = Outer Western Carpathians; $\mathrm{CWC}=$ Central Western Carpathians, divided into the Tatric, Veporic and Gemeric basement-cover complexes (Late Cretaceous tectonic units) overlain by small (often less than kilometre size) fragments of the Meliata tectonic Unit (according to Biely et al. 1996).

hydrothermal systems was documented by Gieré (1990). Main products of Prv replacement in kimberlite - kassite, anatase, titanite, calcite, ilmenite and a LREE-Ti oxide were reported by Mitchell and Chakhmouradian (1998). In melilitic rocks, Prv is typically replaced by $\mathrm{Mg}$ - and Al-poor Ti-rich andradite, commonly accompanied by titanite (Chakhmouradian and Mitchell 1997).

The perovskite-andradite-bearing serpentinized harzburgites, associating with blueschist-facies rocks, found in Slovakia (the Western Carpathians), could be of reaction-metasomatic origin. Radvanec (2009) and Radvanec et al. (2009a) reported the occurrence of 20-50 $\mu \mathrm{m}$ Prv, partly replaced by pyrophanite, from a pale decimetresize fragment in the Danková serpentinite near Dobšiná town, eastern Slovakia. Zajzon et al. (2010) found pyrophanite with about $30 \mu \mathrm{m}$ relic cores of Prv from serpentinite at Perkupa village, northern Hungary (Bódva
Valley, Meliata Unit?). Putiš et al. (2011a, 2012) found homogeneous and/or zoned 30-300 $\mu \mathrm{m}$ Prv crystals enclosed in orthopyroxene porphyroclasts of a serpentinized harzburgite in a quarry at Dobšiná, which is the subject of this study.

This manuscript describes four evolution stages (the E1 to E4 events in text), focusing on perovskite and andradite genesis, constrained on the basis of field geological study, petrography, mineral chemistry, $\mathrm{X}$-ray microtomography for $3 \mathrm{D}$ analysis of Prv distribution, in combination with the wholerock major- and trace-element geochemistry. We attempt to reconstruct these events from the decimetre-sized serpentinized harzburgite fragments of a blueschist-bearing mélange complex.

\section{Geological setting}

\subsection{The Central and Inner Western Carpathians}

The studied Prv-bearing serpentinized harzburgites from Dobšiná belong to the Jurassic mélange complex of the Meliata tectonic Unit, having been formed due to closure of the mid-Triassic-Jurassic Meliata Oceanic Basin. It represents the Inner Western Carpathians (Mock et al. 1998 and citations therein), because this unit builds small nappes thrust over the Central Western Carpathians (Fig. 1). The Alpidic orogenic cycle started roughly before $245 \mathrm{Ma}$ in the Anisian with continental break-up and opening of the Meliata Ocean (Kozur 1991), probably as a back-arc basin, due to northward subduction of the Paleotethys oceanic crust beneath the Eurasian continent (Stampfli 1996). The axial zones of the Meliatic oceanic rift were marked by the BAB and MORB-type basalts (Ivan 2002; Faryad et al. 2005). The first eupelagic sediments, radiolarites, are of Ladinian age (Mock et al. 1998). Deepwater pelagic sedimentation continued until the Late Jurassic in the Meliata Oceanic Basin and terminated with chaotic olistostrome/ mélange bodies developed within the Meliatic accretionary wedge-trench system. 
The association of sediments, basalts, dolerite dykes, gabbros and serpentinized mantle peridotites found in the Meliata Unit clearly indicates an oceanic suite as assumed by Kozur and Mock (1985, 1997). Part of metabasalts reveal a N-MORB $\left[(\mathrm{La} / \mathrm{Sm})_{n}=0.6-0.9\right]$ composition (Ivan 2002; Faryad et al. 2005). Traces of obducted oceanic crust (blocks of basalts alternating with radiolarite layers) were also identified from deepwater sedimentary breccias with radiolaritic matrix (Putiš et al. 2011b). The Neotethyan Meliata Oceanic back-arc Basin closed in Late Jurassic, according to ${ }^{40} \mathrm{Ar}-{ }^{39} \mathrm{Ar}$ ages of "phengitic" white mica from the blueschists (Dallmeyer et al. 1996; Faryad and Henjes-Kunst 1997). The Meliatic subduction-accretionary wedge (Putiš et al. 2011b) was later incorporated into Cretaceous orogenic wedge of the Central Western Carpathians (Plašienka et al. 1997). Its formation was dated by ${ }^{40} \mathrm{Ar}-{ }^{39} \mathrm{Ar}$ method on white micas from c. 130 to $50 \mathrm{Ma}$ (Putiš et al. 2009). From c. $130 \mathrm{Ma}$, the Meliatic subduction-accretionary wedge was rebuilt into numerous, mostly small nappe sheeted bodies, thrust over the Gemeric and Veporic units of the Central Western Carpathians. However in Late Albian (at c. $100 \mathrm{Ma}$ ) some of these nappes were already overlying the frontal part of the Central Western Carpathians orogenic wedge, yielding material to deepwater sediments of the southern Penninic Basin (Dal Piaz et al. 1995; Putiš et al. 2008).

\subsection{Dobšiná locality}

The Dobšiná quarry (N 48 49.622, E 20²1.977) is located in a tectonic fragment of the Meliata tectonic Unit overlying the Gemeric tectonic Unit (Fig. 1). The locality is famous for the occurrence of yellow-green Cr-rich andradite (demantoid) in serpentinite fissures (Fediuková et al. 1976; Hovorka et al. 1984, 1985).

The association of the exposed rocks indicates a mélange complex within a frontal (subduction-) accretionary wedge (Putiš et al. 2011b). Harzburgite seems to be the most abundant original ultramafic rock type in the Late Jurassic (to Early Cretaceous?) serpentinite-blueschist mélange complex in this quarry. The mélange complex is composed here of the talc-phengite-glaucophane schists, marbles, metaconglomerates, blueschists of magmatic and sedimentary origin, serpentinites. All rocks form decimetre- to 100 metre-sized fragments within the Late Jurassic very low temperature greenschist-facies metasediments. Harzburgitic, nearly spherical fragments of variable size (a few centimetres to 3 metres) occur in the serpentinite matrix. The best macroscopic indicator of potential Prv occurrence are relic dark spherical only weakly serpentinized harzburgitic "cores", $1-20 \mathrm{~cm}$ in diameter, surrounded by greenish distinctly serpentinitized rims. This "frontal" serpentinization zone in rims is typical of Prv occurrence. Similar ultramafic cores in ser- pentinites of the Dobšiná quarry were found by Hovorka et al. (1984, photo 4), without mentioning Prv in serpentinite country rocks. The harzburgite blocks have typical rounded shape. They most likely represent exhumed blocky fragments of metaultramafics from subduction channel rotated within the more plastic serpentinite matrix during their exhumation. Mechanical disintegration and abrasion combined with serpentinization resulted in different size of these fragments.

\section{Methods}

Twenty-eight samples of serpentinized harzburgite, collected in the Dobšiná quarry, contain Prv, but only about ten of them were suitable for a detailed study because of strong alteration. In total 188 polished sections from 110 samples were examined under Leica DM2500 P polarizing microscope equipped with $\mathrm{CCD}$ camera, at the Comenius University in Bratislava.

Mineral compositions (Tab. 1) were determined by Cameca SX-100 electron microprobe at the State Geological Institute of Dionýz Štúr in Bratislava. Analytical conditions of electron analyzer were $15 \mathrm{kV}$ accelerating voltage and $20 \mathrm{nA}$ beam current. Cameca Peak Sight v4.2 software was used for recalculation of measured data. We used these standards for calibration: $\mathrm{Na}$ on albite, $\mathrm{Si}$, $\mathrm{Ca}$ on wollastonite, $\mathrm{K}$ on orthoclase, $\mathrm{Mg}$ on forsterite, $\mathrm{Al}$ on $\mathrm{Al}_{2} \mathrm{O}_{3}, \mathrm{Fe}$ on fayalite, $\mathrm{Mn}$ on rodonite, metallic $\mathrm{V}$, $\mathrm{Cr}$, and $\mathrm{Ni}$, Ti on $\mathrm{TiO}_{2}, \mathrm{Sr}$ on $\mathrm{SrTiO}_{3}, \mathrm{Nb}$ on $\mathrm{LiNbO}_{3}, \mathrm{La}$ on $\mathrm{LaPO}_{4}, \mathrm{Ce}$ on $\mathrm{CePO}_{4}$, and $\mathrm{Ta}$ on $\mathrm{LiTaO}_{3}$. The beam diameter used was $10 \mu \mathrm{m}$ except for pyroxene lamellae $(2-5 \mu \mathrm{m})$.

Whole-rock major- and trace-element analyses were determined by X-ray fluorescence spectrometry (XRF) using a PHILIPS PW 2400 (Department of Lithospheric Research, University of Vienna). Samples were cleaned, crushed in a metal jaw crusher and grounded in agate disc mill. Powdered whole-rock samples were dried in an oven at $110{ }^{\circ} \mathrm{C}$ overnight and heated in muffle furnace at $1050{ }^{\circ} \mathrm{C}$ for $3 \mathrm{~h}$ to determine loss on ignition. For major elements, lithium-tetraborate $\left(\mathrm{Li}_{2} \mathrm{~B}_{4} \mathrm{O}_{7}\right)$ melt beads and for the trace elements pressed powder pellets were used. The former were casted using Philips Perl X3 automatic bead machine. Rhodium anticathode was employed for the XRF analyses.

Trace-element (including rare earth elements - REE) contents were analyzed by inductively coupled plasma mass spectrometry (ICP-MS) at the General and Analytical Chemistry, Montanuniversität Leoben. In total $0.1 \mathrm{~g}$ of fine grained sample was sintered with sodium peroxide to achieve complete digestion of all silicates and chromitite (Meisel et al. 2002). Certified and uncertified reference materials digested in the same way were used for external calibration. Measurements were performed with a Agi- 


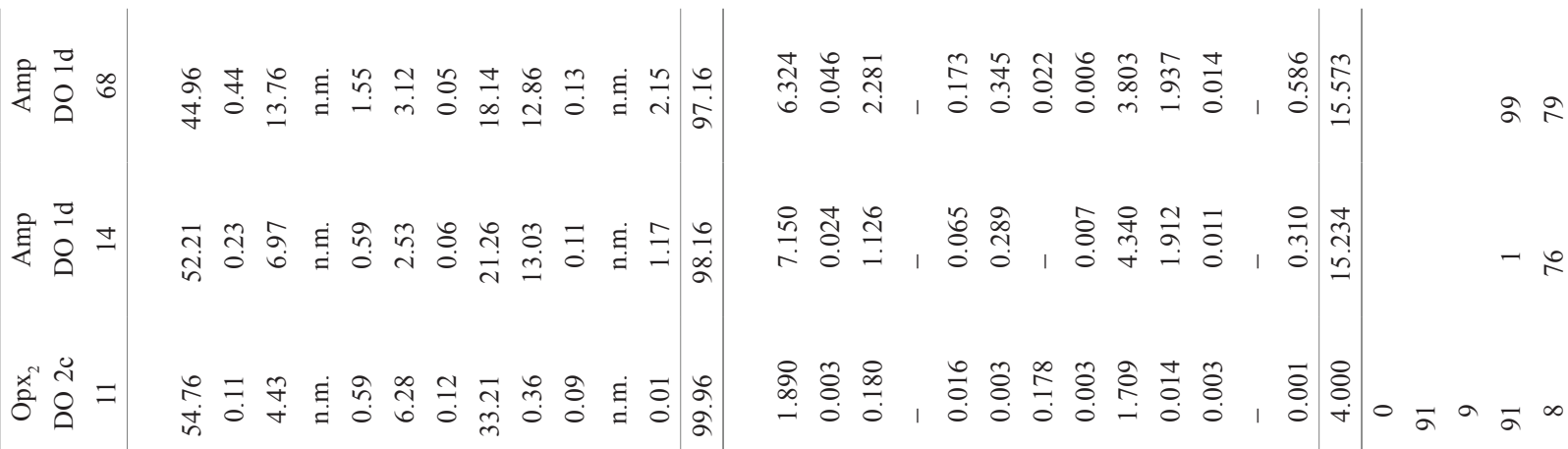
商当 焉 $\stackrel{1}{2}$

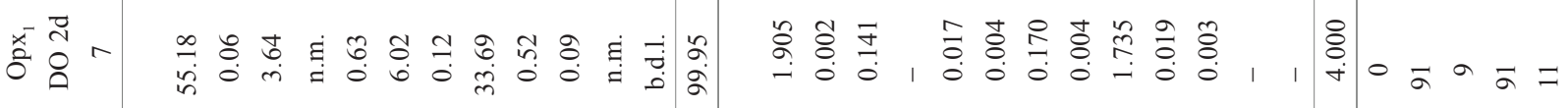

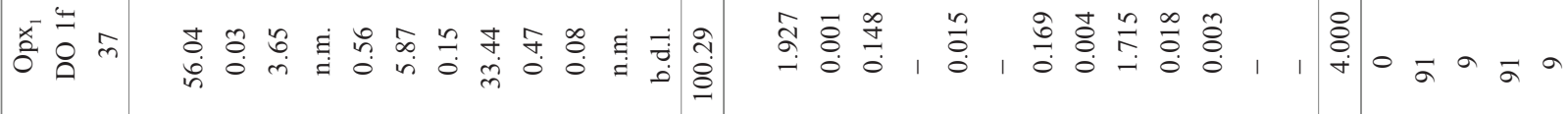
莡

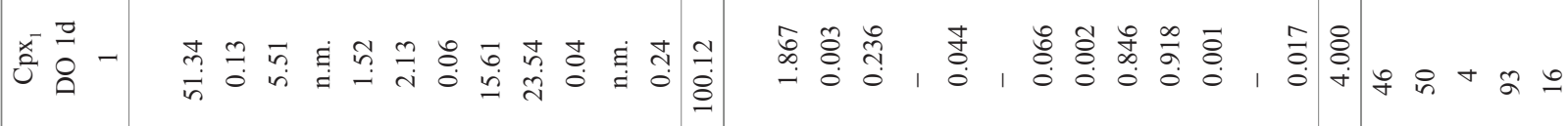

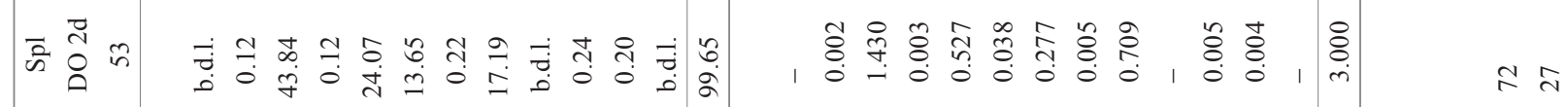

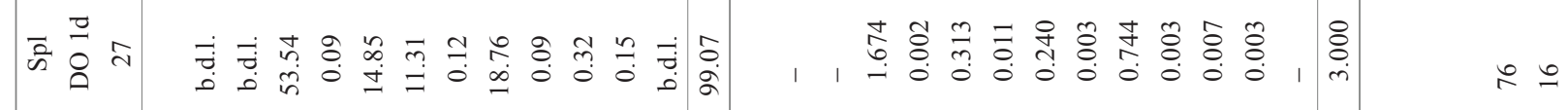

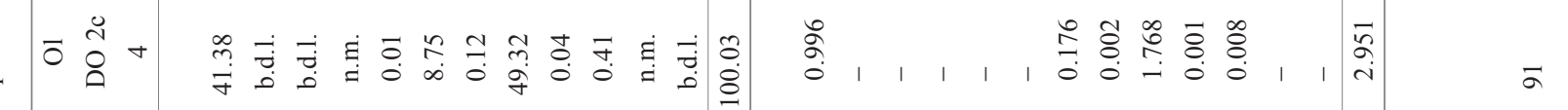

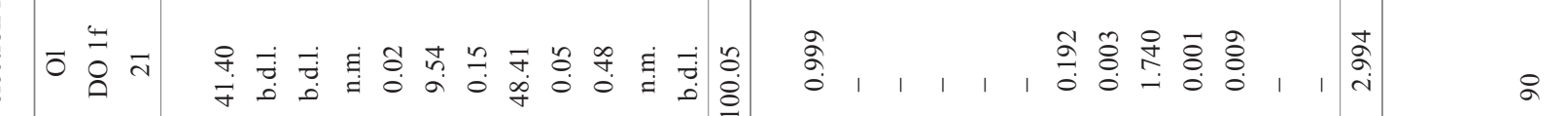
焉焉 


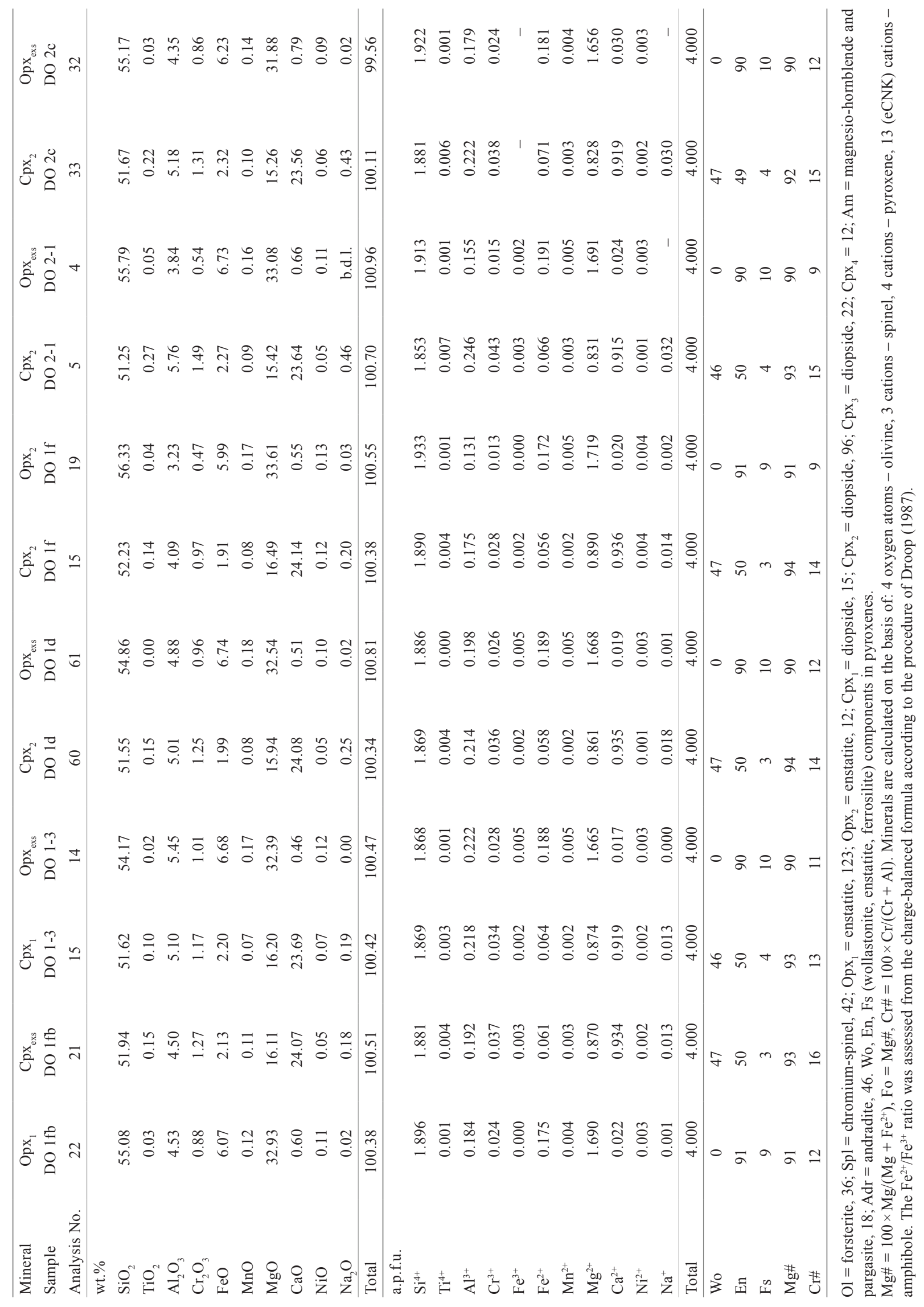


Tab. 1 (Continuation) Representative electron microprobe analyses of minerals from harzburgite with number of all measurements of a given mineral

\begin{tabular}{|c|c|c|c|c|c|c|c|}
\hline Mineral & Prv & Prv & Pph & Pph & Mineral & Ti-Adr & Ti-Adr \\
\hline Sample & DO $2 F-1 B 1$ & DO2f-1B1 & DO 2-3 & DO 2-3 & Sample & DO $2 \mathrm{~F}$ & DO $2 f$ \\
\hline Analysis No. & 1 & 2 & 5 & 12 & Analysis No. & 1 & 2 \\
\hline wt. $\%$ & & & & & wt. $\%$ & & \\
\hline $\mathrm{SiO}_{2}$ & b.d.l. & 0.03 & 0.11 & b.d.1. & $\mathrm{SiO}_{2}$ & 34.03 & 33.42 \\
\hline $\mathrm{TiO}_{2}$ & 56.72 & 57.39 & 51.36 & 51.21 & $\mathrm{TiO}_{2}$ & 5.99 & 6.05 \\
\hline $\mathrm{Al}_{2} \mathrm{O}_{3}$ & 0.02 & b.d.l. & b.d.1. & b.d.1. & $\mathrm{Al}_{2} \mathrm{O}_{3}$ & 0.33 & 0.24 \\
\hline $\mathrm{Cr}_{2} \mathrm{O}_{3}$ & 0.38 & 0.34 & 0.03 & 0.34 & $\mathrm{~V}_{2} \mathrm{O}_{3}$ & 0.06 & 0.04 \\
\hline $\mathrm{FeO}$ & 0.91 & 0.61 & 2.91 & 2.49 & $\mathrm{Cr}_{2} \mathrm{O}_{3}$ & 2.09 & 2.13 \\
\hline $\mathrm{MnO}$ & b.d.l. & b.d.l. & 40.96 & 43.45 & $\mathrm{Fe}_{2} \mathrm{O}_{3}$ & 20.68 & 21.49 \\
\hline $\mathrm{MgO}$ & b.d.l. & b.d.l. & 0.24 & 0.12 & $\mathrm{FeO}$ & 1.42 & 0.53 \\
\hline $\mathrm{CaO}$ & 40.28 & 40.26 & 1.89 & 0.77 & $\mathrm{MnO}$ & 0.02 & 0.07 \\
\hline $\mathrm{NiO}$ & b.d.l. & b.d.l. & b.d.1. & b.d.1. & $\mathrm{MgO}$ & 0.68 & 0.76 \\
\hline $\mathrm{Na}_{2} \mathrm{O}$ & 0.03 & b.d.l. & b.d.1. & b.d.1. & $\mathrm{CaO}$ & 33.86 & 33.77 \\
\hline $\mathrm{La}_{2} \mathrm{O}_{3}$ & 0.33 & 0.21 & b.d.l. & b.d.l. & $\mathrm{Na}_{2} \mathrm{O}$ & 0.01 & 0.04 \\
\hline $\mathrm{Ce}_{2} \mathrm{O}_{3}$ & 1.17 & 0.93 & 0.13 & 0.13 & Total & 99.17 & 98.54 \\
\hline Total & 99.82 & 99.74 & 97.52 & 98.51 & a.p.f.u. & & \\
\hline a.p.f.u. & & & & & $\mathrm{Si}^{4+}$ & 2.875 & 2.843 \\
\hline $\mathrm{Si}^{4+}$ & - & 0.001 & 0.003 & - & $\mathrm{Ti}^{4+}$ & 0.380 & 0.387 \\
\hline $\mathrm{Ti}^{4+}$ & 0.981 & 0.991 & 0.984 & 0.978 & $\mathrm{Al}^{3+}$ & 0.033 & 0.024 \\
\hline $\mathrm{Al}^{3+}$ & 0.001 & - & - & - & $\mathrm{V}^{3+}$ & 0.004 & 0.003 \\
\hline $\mathrm{Cr}^{3+}$ & 0.007 & 0.006 & 0.006 & 0.007 & $\mathrm{Cr}^{3+}$ & 0.140 & 0.143 \\
\hline $\mathrm{Fe}^{3+}$ & 0.016 & 0.006 & 0.013 & 0.028 & $\mathrm{Fe}^{3+}$ & 1.315 & 1.376 \\
\hline $\mathrm{Fe}^{2+}$ & 0.002 & 0.006 & 0.049 & 0.026 & $\mathrm{Fe}^{2+}$ & 0.100 & 0.037 \\
\hline $\mathrm{Mn}^{2+}$ & - & - & 0.884 & 0.935 & $\mathrm{Mn}^{2+}$ & 0.001 & 0.005 \\
\hline $\mathrm{Mg}^{2+}$ & - & - & 0.009 & 0.005 & $\mathrm{Mg}^{2+}$ & 0.086 & 0.096 \\
\hline $\mathrm{Ca}^{2+}$ & 0.992 & 0.990 & 0.052 & 0.021 & $\mathrm{Ca}^{2+}$ & 3.064 & 3.079 \\
\hline $\mathrm{Ni}^{2+}$ & - & - & - & - & $\mathrm{Na}^{+}$ & 0.002 & 0.006 \\
\hline $\mathrm{Na}^{+}$ & 0.001 & - & - & - & Total & 8.000 & 8.000 \\
\hline \multirow[t]{5}{*}{ Total } & 2.000 & 2.000 & 2.000 & 2.000 & Prp & 2.94 & 3.14 \\
\hline & & & & & Sps & 0.06 & 0.09 \\
\hline & & & & & Alm & 1.74 & 0.60 \\
\hline & & & & & Adr & 67.93 & 70.96 \\
\hline & & & & & Grs & 27.34 & 25.22 \\
\hline
\end{tabular}

Prv $=$ perovskite, $69 ; \mathrm{Pph}=$ pyrophanite, $15 ; \mathrm{Adr}=$ andradite, 58.

Minerals are calculated on the basis of: 2 cations - perovskite and pyrophanite, 8 cations - Ti-rich Adr garnet. Formulae of garnets were obtained on the basis of 8 cations and 24 negative charges. The $\mathrm{Fe}^{2+} / \mathrm{Fe}^{3+}$ ratio was assessed from the charge-balanced formula according to the procedure of Droop (1987).

lent 7500 ce ICP-MS with and without He collision cell mode. International Association of Geoanalysts (IAG) Candidate reference material MUH-1, a highly depleted, serpentinized harzburgite from Kraubath, Styria, Austria (Burnham et al. 2010), was used for quality control purposes (see the Electronic Supplementary Material).

The preceding sodium peroxide (purity $>95 \%$ ) sintering and acid digesting $(37 \% \mathrm{HCl})$ followed the procedures of Meisel et al. (2002). As a reference material was employed a solution with very accurately known concentrations of Ge, In and Re $(1 \mu \mathrm{l} / \mathrm{ml})$. The machine used was a standard quadrupole ICP-MS Agilent Technologies HP4500 with a v-groove type Babington or a
Burgener pumped nebulizer and a cooled quartz glass spray chamber.

The size, shape and distribution analysis of Prv grains was carried out on drilled cylindrical specimens, $1 \mathrm{~cm}$ in diameter, sampled along a profile, $c .20 \mathrm{~cm}$ long, from the dark core to the greenish serpentinized zone, by X-ray micro-tomograph Nanotom 180 at the Institute of Measurement of Science of the Slovak Academy of Sciences in Bratislava. A characteristic X-ray absorption of Prv, besides the other physical properties, such as density and shape, enabled to visualize the Prv crystals distribution in serpentinite matrix and distinguish them from other silicate, oxide and carbonate minerals. 

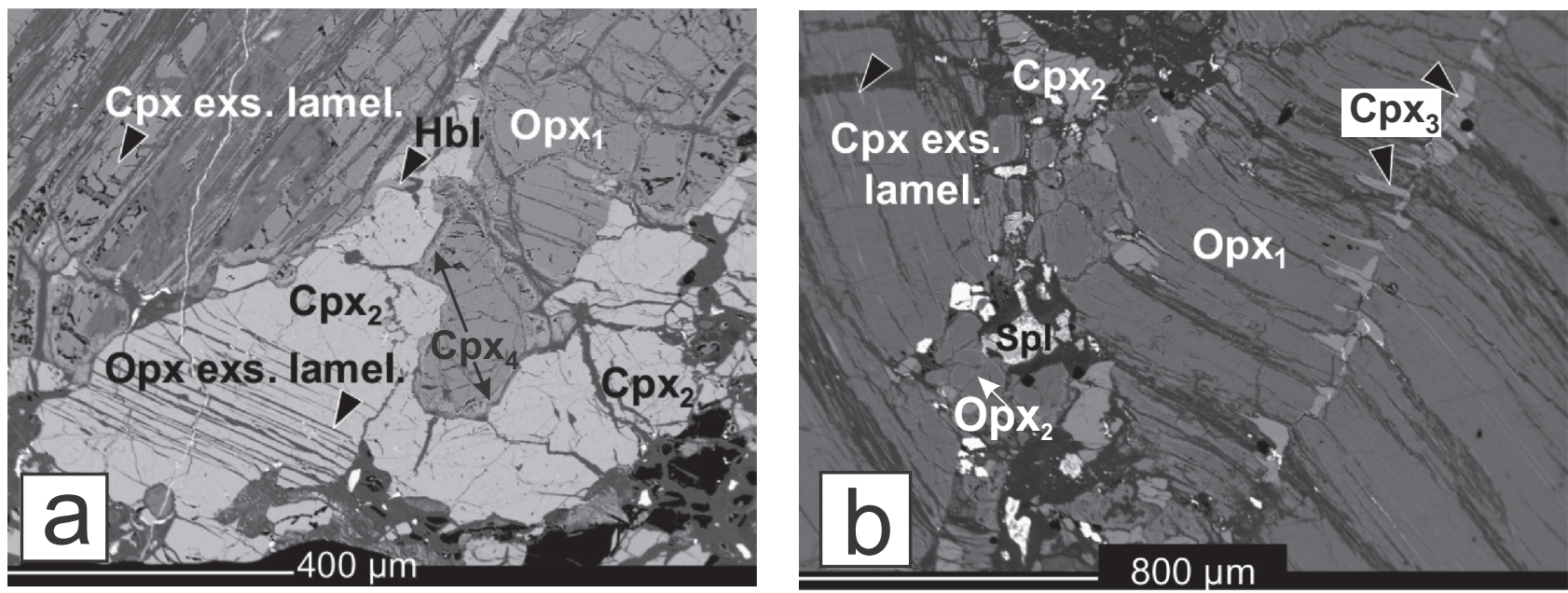

Fig. 2a - Back-scattered electron (BSE) image of $\mathrm{Opx}_{1}$ (E1 event) partly replaced and enclosed by late-magmatic $\mathrm{Cpx}{ }_{2}$ and rare $\mathrm{Cr}-\mathrm{Spl}$ (E2 event). Metamorphic lower-Al $\mathrm{Cpx}_{4}$ pale rim with Prg (E4 event; sample DO-1d; DO = Dobšiná locality) follow the boundary between the Opx ${ }_{1}$ and $\mathrm{Cpx}_{2}$ aggregate, indicating percolation of metamorphic fluids. $\mathbf{b}-\mathrm{BSE}$ image of late-magmatic $\mathrm{Cpx}_{2}(\mathrm{Spl})$ aggregates at the rim of the Opx ${ }_{1}$ porphyroclasts; the cleavage planes of kinked porphyroclasts are infilled by subsolidus (E2) recrystallization aggregates of $\mathrm{Cpx}_{3}(\mathrm{~s}$. DO-1f).

Mineral abbreviations used in text, tables and figures are after Whitney and Evans (2010): Act = actinolite, $\mathrm{Adr}=$ andradite, $\mathrm{Alm}=$ almandine (component) $\mathrm{Amp}=$ amphibole (group), Ap = apatite, Atg = antigorite, $\mathrm{Chl}$ $=$ chlorite, $\mathrm{Cpx}=$ clinopyroxene, $\mathrm{Ctl}=$ chrysotile, $\mathrm{Di}=$ diopside, $\mathrm{Ep}=$ epidote, $\mathrm{Grs}=$ grossular $($ component $)$, $\mathrm{Grt}=$ garnet, $\mathrm{Hem}=$ hematite, $\mathrm{Hbl}=$ hornblende, $\mathrm{Lz}=$ lizardite, $\mathrm{Mag}=$ magnetite, $\mathrm{Ol}=$ olivine, $\mathrm{Opx}=$ orthopyroxene, $\operatorname{Prg}=$ pargasite, $\mathrm{Pph}=$ pyrophanite $\operatorname{Prp}=$ pyrope (component), $\mathrm{Prv}=$ perovskite, $\mathrm{Qz}=$ quartz, $\mathrm{Spl}=$ spinel, $\mathrm{Sps}=$ spessartine $($ component $), \mathrm{Srp}=$ serpentine minerals (undistinguished), Tlc $=$ talc, Ves $=$ vesuvianite, except for $\mathrm{Carb}=$ carbonates.

\section{Results}

\subsection{Petrography and electron microprobe study}

In general, the studied dark harzburgitic cores of rocks boulders, surrounded by greenish to greenish-yellow serpentinite, have granular textures lacking high-T foliation and lineation. There are only rare domains in serpentinites, showing relic macroscopic and microscopic lamination due to metamorphic-deformation processes related to serpentinization. Mineral compositions of less altered (only about 10) samples are practically the same and because of this reason we describe below their average or representative modal composition found by microscopic study.

The relic primary magmatic microstructures of slightly serpentinized dark harzburgitic cores consist of $\mathrm{Ol}(c .70$ vol. \%), $\mathrm{Opx}_{1}$ (c. 25 vol. \%), accessory $\mathrm{Cr}-\mathrm{Spl}$ (c. 4 vol. \%) and rare $\mathrm{Cpx}_{1}$ (c. 1 vol. \%). Magmatically corroded and partly dissolved porphyric $\mathrm{Opx}_{1}\left( \pm \mathrm{Cpx}_{1}\right)$ is enclosed in olivine matrix with $\mathrm{Cr}-\mathrm{Spl}$. Both pyroxenes show exsolution lamellae, of $\mathrm{Cpx}$ in $\mathrm{Opx}_{1}$, or $\mathrm{Opx}$ in $\mathrm{Cpx}_{1}$, respectively (Fig. 2a).

Effects of subsolidus deformation of $\mathrm{Opx}_{1}\left( \pm \mathrm{Cpx}_{1}\right)$ porphyroclasts by kinking and rotation are seen. Aggregates of late-magmatic $\mathrm{Cpx}_{2}$ (c. $10 \mathrm{vol} . \%$, at the expense of dissolved $\mathrm{Opx}_{1}$ ) with (c. 1 vol. \%) Cr-Spl (Fig. 2a), and scarce aggregates of $\mathrm{Opx}_{2}$ (Fig. 2b) occur at the rim of the $\mathrm{Opx}{ }_{1}$ porphyroclasts. Microfractures and cleavage planes of the kinked and rotated $\mathrm{Opx}_{1}$ porphyroclasts are filled by $\mathrm{Cpx}_{3}$ (Al-rich), the latter representing the late-magmatic subsolidus (syn-HT deformation) recrystallization of the $\mathrm{Opx}_{1}$ porphyroclasts (Fig. 2b). Cloudy lower Al (1.2-2.5 wt. \%) $\mathrm{Cpx}_{4}$ associated with Prg occurs in reaction rims between the $\mathrm{Opx}_{1}$ and $\mathrm{Cpx}_{2}$. Rarely Ol is consumed by antigorite coronas. Central parts of the $\mathrm{Cpx}_{2}$ grains contain exsolution lamellae of Opx (Fig. 2a), enclosed in metamorphic diopsidic rim $\left(\mathrm{Cpx}_{5}\right.$, with very low $\mathrm{Al}_{2} \mathrm{O}_{3}$ contents of $0.02-0.1$ wt. \%). Scarcely present $\mathrm{Opx}_{2}$ contains Cpx exsolution lamellae, as well.

Perovskite usually occurs in close vicinity to the dark (Prv-free) slightly hydrated harzburgitic cores of serpentinite boulders. The perovskite crystals, set within the serpentinized $\mathrm{Opx}_{1}$ porphyroclasts, are either chemically homogeneous or they show sector zoning (Fig. 3a) in back-scattered electron (BSE) images. Many of them exhibit two types of lamellae. Yellow-brown Prv crystals show two systems of secondary polysynthetic lamellae under the optical microscope. These are perpendicular to each other (Fig. 3b), and oblique to Cpx exsolution lamellae in the hosting $\mathrm{Opx}_{1}$. They could be connected with the Prv phase transformations or deformation. On 

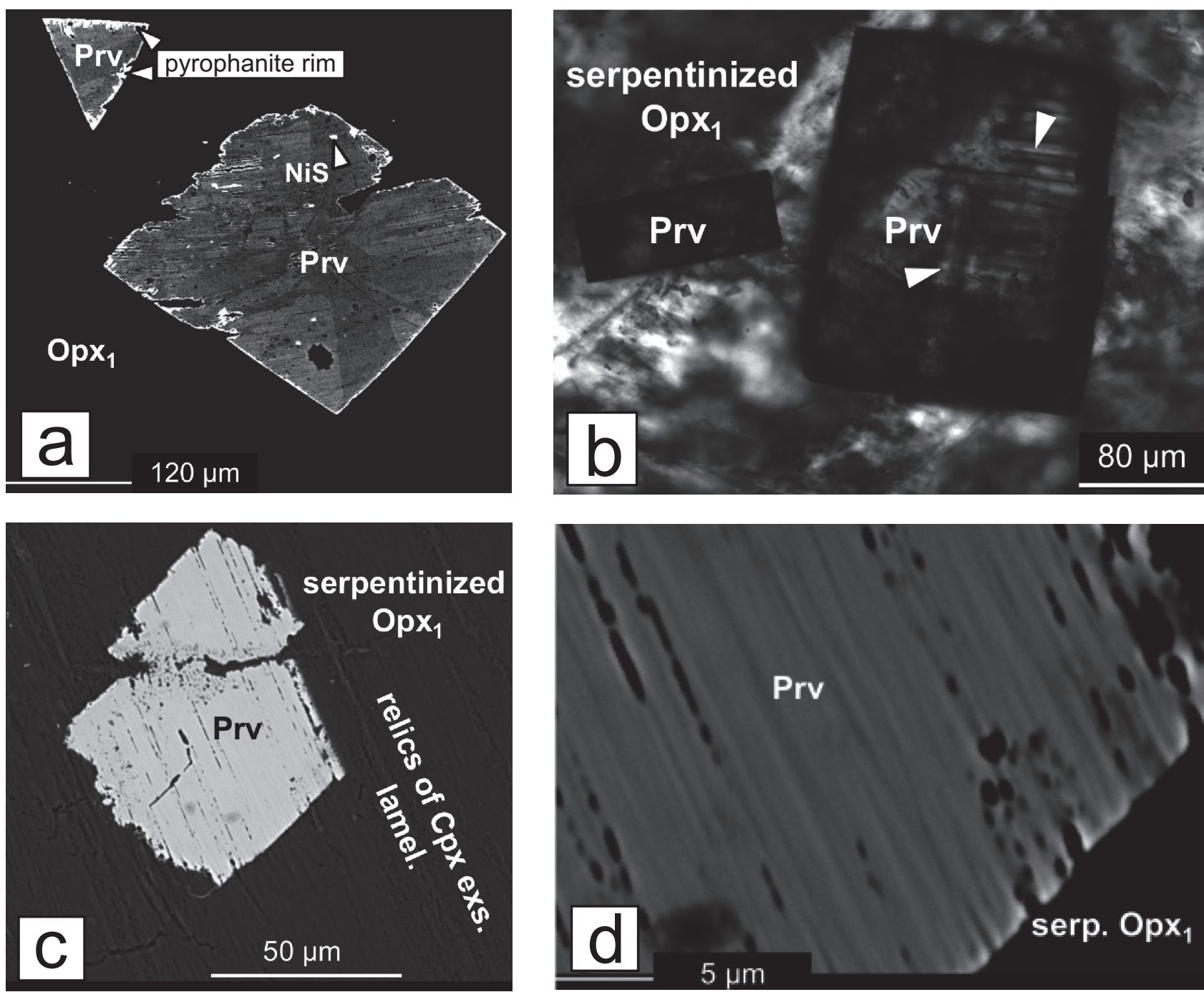

Fig. 3a - Back-scattered electron (BSE) image of sector-zoned, partly resorbed Prv in serpentinized Opx ${ }_{1}$ (sample DO-2-3). Brighter domains in Prv indicate a higher content of REE (mainly La and Ce). Prv is partly replaced by pyrophanite pale thin rims (late E4 event). b - PL image of Prv polysynthetic lamellae (arrows), enclosed in serpentinized $\mathrm{Opx}_{1}$ (s. DO-2-3). c - BSE image of lamellar Prv grown parallel to the Cpx exsolution lamellae. Partial dissolution of Prv due to serpentinization (s. DO-2f-1). d - Detail of c, showing chemical zoning in Prv, parallel to growth lamellae (E4 event).

the other hand, the growth lamellae system is observable in BSE, and this runs parallel to the Cpx exsolution lamellae, most likely (100) crystallographic plane system (Fig. 3c-d). Morphology of the Prv crystals (Fig. 4a-c) varies from single lamellae, $10-30 \mu \mathrm{m}$ thick (parallel to the Cpx exsolution lamellae) to cube crystals (50-300 $\mu \mathrm{m}$ in size) or their aggregates (300-600 $\mu \mathrm{m}$ across).

Some of the $\mathrm{Opx}_{1}$ in greenish-yellowish rodingitized domains of serpentinites enclose fine- to coarse-grained aggregates of Ti-rich and common Adr (Fig. 5a-b). Platy, prismatic to cube crystals of the (sometimes Ti-rich) Adr are oriented again parallel to the Cpx exsolution lamellae. Morphology of both the Prv and (Ti-rich) Adr crystals could indicate their growth mainly at the expense of $\mathrm{Cpx}$ exsolution lamellae in the $\mathrm{Opx}_{1}$.
It is important to note that this Prv generation does not usually appear in the same alteration zone of serpentinites as Adr does. Although they can occur in the same thin section, aggregates of these minerals enclosed in $\mathrm{Opx}_{1}$ porphyroclasts are not mixing and are strictly separated from each other. Andradite seems to be younger than perovskite because the former is characteristically bound to the yellowish (to white-coloured) zones of rodingitization often crosscutting the Prv-bearing serpentinite in form of veins and veinlets. Because of similarities in described crystal morphology between Prv and especially Ti-rich Adr, one can not exclude that at least part of the Ti-rich Adr in the $\mathrm{Opx}_{1}$ porphyroclasts consumed Prv. In general, Adr indicates rodingitization domains, rather than serpentinization zones alone. Rarely, inclusions of 


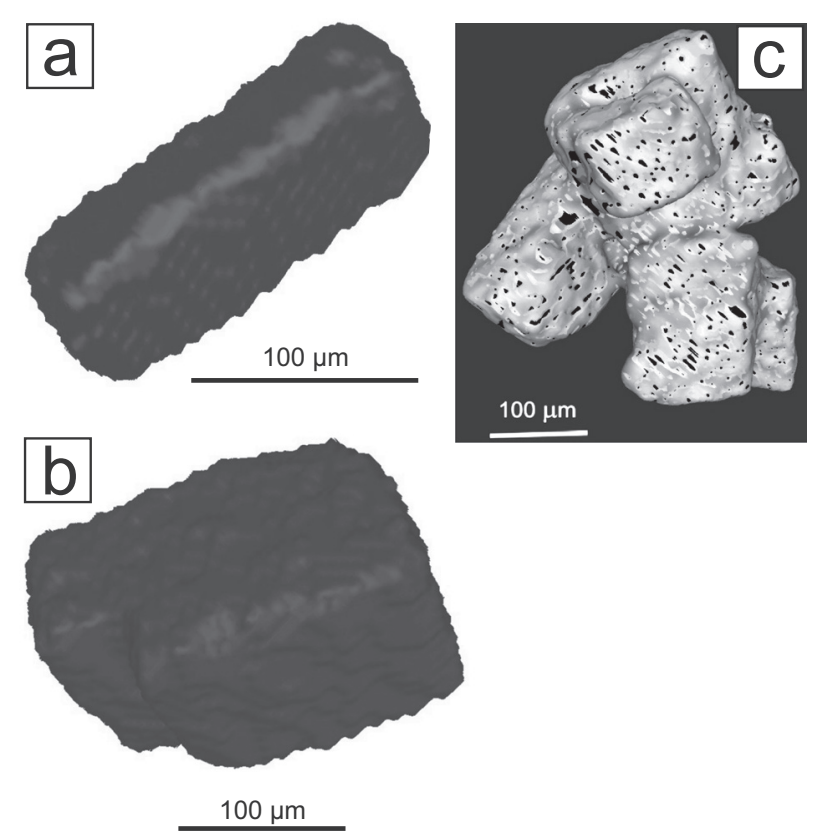

Fig. 4 Basic morphological types of Prv from 3D X-ray micro-tomography (sample DO-2-3). The artificial colour shade was chosen for showing the morphology details: $\mathbf{a}$ - single lamella; $\mathbf{b}$ - two-lamellae (prismatic to cube-shaped, elsewhere); $\mathbf{c}$ - an aggregate of crystals.

platy Ti-rich Adr (parallel to Cpx exsolution lamellae of serpentinized $\mathrm{Opx}$, porphyroclasts) were found in the last generation of common (Ti-poor, Cr-rich) large greenish Adr grains (demantoid).

Thin alteration rims of pyrophanite are observable on Prv (Figs 3a, 4c) from serpentinites. The common or predominating mineral assemblage of a hosting greenish serpentinite contains Srp, Chl, Act to Hbl, Carb, Tlc, (Cr-Fe) Spl, Mag, Hem, Qz and Pph. Green-yellowish to yellowish alteration zones usually contain Ti-rich, or Ti-poor Adr (demantoid) mainly as a result of rodingitization accompanying serpentinization.

Macroscopically, according to colour, there are at least three zones distinguishable in studied serpentinites, indicating differences in mineral and chemical compositions. These are, from the centre to rim: (1) a dark harzburgite core, with negligible effects of serpentinization and/or rodingitization (missing Prv and Adr), surrounded by (2) greenish zone of serpentinization (present Prv, usually missing Adr), and (3) yellowish zone of rodingitization (restricted occurrence or missing Prv, present Ti-rich and/or Ti-poor Adr).

The serpentinized zone (2) can be furthermore subdivided to (2a) a $1-20 \mathrm{~cm}$ wide inner zone, with relics of magmatic minerals (Prv often present, Adr missing), (2b) transitional greenish-yellowish zone, in which are Prv, Ti-rich and Ti-poor Adr often common but they occur separately in cm-sized domains, and (2c) pure serpentinite, without mineral relics (missing Prv and/ or Adr).

Recently we however found a newer skeletal to veined $\operatorname{Prv}(2)$ within centimetre-sized chlorite-rich veins in the Adr-Ep-Ves-Di-Ap-rich rodingites. This Prv is partly to almost totally replaced and surrounded by Ti-rich Adr halos (containing up to 14 wt. $\%$ of $\mathrm{TiO}_{2}$ ) enclosed in common Adr (Fig. 5c-d). Although these domains of Prv-Adr occurrences in rodingites have not yet been studied in detail, they are the best evidence that Ti-rich Adr in both serpentinites and rodingites was spatially closely related to Prv.

\subsection{Characterization of evolution events}

This section reviews evolutionary stages of the studied Prv- and/or Adr-bearing harzburgite, termed events E1 to E4 here. They were derived from microstructures, mineral and whole-rock chemical data. Although wellpreserved dark magmatic harzburgitic cores are rare and partly altered in serpentinite boulders, they still yield some important information on the magmatic (E1) and partial melting (E2) mantle events. The main attention was however focused on later E3, and especially on the E4 event, with signatures of fluid-rock interaction and genesis of perovskite and andradite as well.

\subsubsection{The E1 magmatic mantle event}

The Cpx-poor harzburgites (Cpx harzburgites, further in text) from the preserved dark cores of serpentinite boulders are characterized by relatively low contents of $\mathrm{TiO}_{2}(0.02-0.03$ wt. \%), $\mathrm{CaO}(0.98-2.02$ wt. \%) and $\mathrm{Al}_{2} \mathrm{O}_{3}$ (1.14-1.51 wt. \%) (Tab. 2) if compared to Primitive Mantle (McDonough and Sun 1995). Their modal composition features two different generations of magmatic Al-rich pyroxenes and low Cr-Spl (Cr\#: 15-30).

The $\mathrm{TiO}_{2}$ content of the Dobšiná harzburgitic rocks (Tab. 2) is very low (0.02-0.03 wt. \%), suggesting that this element was not added from any external source during the later metamorphic-metasomatic (E3 and/or E4) events. However, a tendency to a strong loss of $\mathrm{CaO}$ towards serpentinite rims of harzburgitic cores (Tab. 2), or a distinct gain in rodingitized serpentinites, can be related to such a process. Only limited, if any, mobility was observed for $\mathrm{SiO}_{2}, \mathrm{TiO}_{2}, \mathrm{Al}_{2} \mathrm{O}_{3}$ and $\mathrm{MgO}$ in both the dark cores and the serpentinized rims of the studied harzburgites.

There was found one exception until now, a second type of ultramafic protolith richer in Cpx with increased contents of $\mathrm{Al}$ and $\mathrm{Ti}$. It could be called $\mathrm{Cpx}$-rich harzburgite, as it contains c. $25 \%$ of $\mathrm{Cpx}_{1,2}$, most likely indicating a very low degree of melting of the original protolith. 

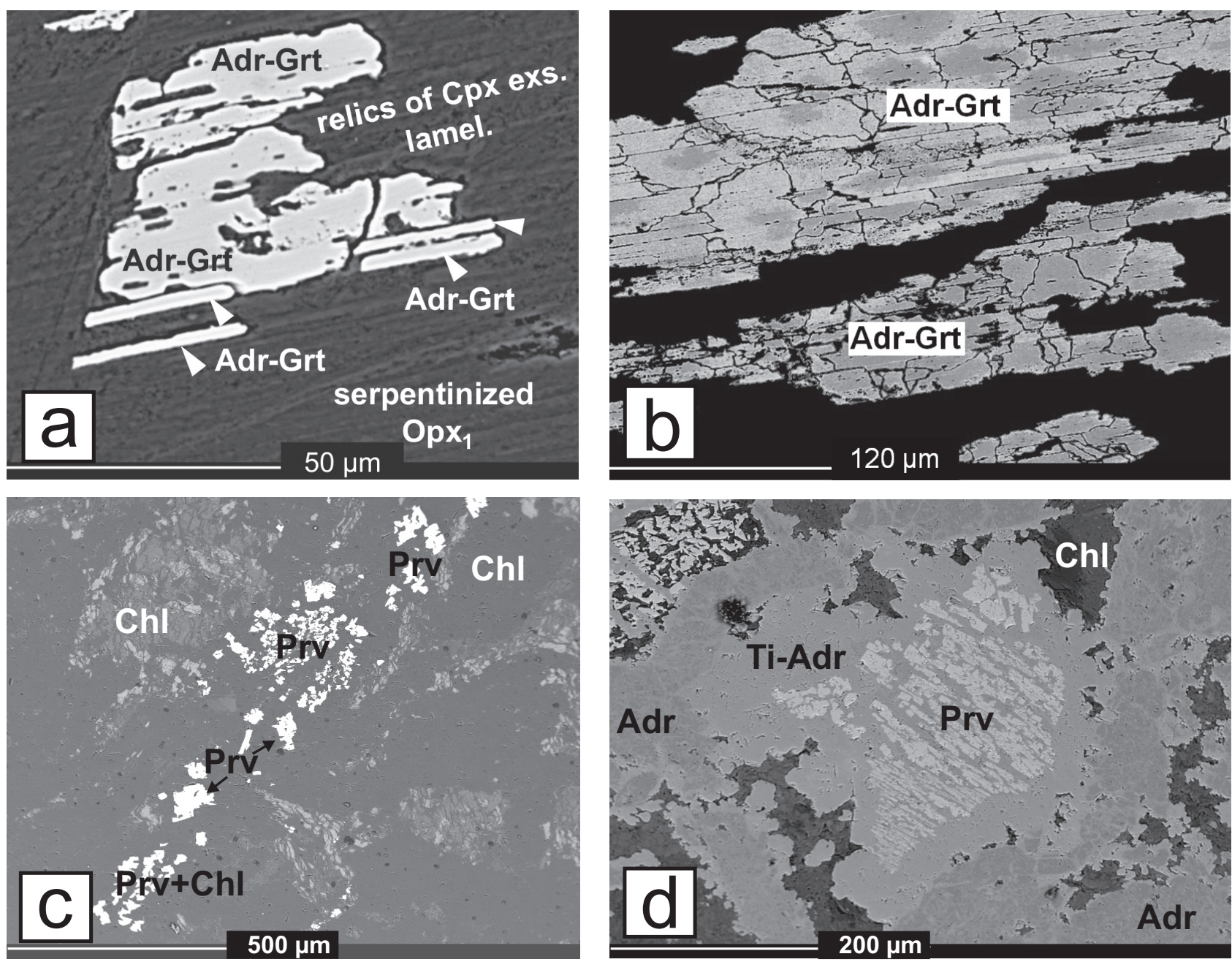

Fig. 5a - Back-scattered electron image of Ti-rich Adr in Opx, porphyroclasts (E4 event; sample DO-2f-2). Morphology of Adr resembles that of Prv: platy to prismatic (arrows), parallel to relics of $\mathrm{Cpx}$ exsolution lamellae in the hosting serpentinized Opx 1 , or bigger cube-shaped crystals. b - Andradite with lamella structure after replacement of Cpx lamellae. Dark domains indicate higher Ti content. Both examples could indicate formation of Ti-rich Adr after Prv. c - vein-type Prv(2). d - Ti-Adr halo around Prv(2) in rodingite.

The $\mathrm{Opx}_{1}$ composition $\left(\mathrm{TiO}_{2}: 0.03-0.1\right.$ wt. $\%, \mathrm{Mg \#}$ : 90-92; Tab. 1) does not exclude formation of the studied Cpx harzburgite in abyssal mantle. It could have formed as a residue after adiabatic melting of an inferred lherzolitic precursor (e.g. Kelemen et al. 1997), resulting from decompression of the mantle beneath spreading Neotethyan, Meliatic ridge. Extension thinning of the mantle lithosphere beneath spreading mid-ocean ridge could have been driven by the northward subduction of the Paleotethyan oceanic slab (Stampfli 1996). The E1 event probably represents melting of original mantle (most likely lherzolitic) peridotite due to mantle upwelling and an inferred subsequent extraction of a basaltic melt, forming an $\mathrm{Ol}-\mathrm{Opx} \mathrm{x}_{1}$-rich weakly depleted harzburgitic residue.

Approximately 15-20 vol. \% degree of melting of the primitive (lherzolitic?) mantle source was estimated according to a visual comparison of bulk rock REE (HREE) patterns of studied harzburgites normalized to PM, with the HREE fractional-melting model of Niu (2004, fig. 9). Low $\mathrm{TiO}_{2}$ contents in $\mathrm{Opx}_{1}(0.03-0.1$ wt. \%) and rare $\mathrm{Cpx}_{1}(0.09-0.18$ wt. \%) indeed speak for their residual character.

Klemme (2004) modelled the Spl- to Grt-lherzolite transition for pressures of 15 to $20 \mathrm{kbar}$ and temperatures between 800 and $1300^{\circ} \mathrm{C}$ for $\mathrm{Cr}$-poor mantle compositions. The same author constrained this transition in $\mathrm{Cr}-$ rich mantle compositions for a pressure of $24 \mathrm{kbar}$ and a temperature of $1400^{\circ} \mathrm{C}$, or a pressure of $17 \mathrm{kbar}$ and a temperature of $1100^{\circ} \mathrm{C}$.

We also used calculation sheet after Putirka (2008) for estimating $\mathrm{P}$ and $\mathrm{T}$ using two-pyroxene-based thermometers. The pressure estimates strongly depend on the assumed temperature. For $1300^{\circ} \mathrm{C}$, a pressure of $20.4 \mathrm{kbar}$ was calculated from $\mathrm{Cpx}_{1}-\mathrm{Opx}_{1}$ pair (analyses no. 29 and 37 in Tab. 1), but it would drop rapidly to $15.9 \mathrm{kbar}$ 
Tab. 2 Representative whole-rock analyses of harzburgite

\begin{tabular}{|c|c|c|c|c|c|c|}
\hline $\begin{array}{l}\text { Sample } \\
\text { Rock type }\end{array}$ & $\begin{array}{l}\text { DO 1d-core } \\
\text { harzburgite }\end{array}$ & $\begin{array}{l}\text { DO 1d-rim } \\
\text { serpentinite }\end{array}$ & $\begin{array}{l}\text { DO 2-core } \\
\text { harzburgite }\end{array}$ & $\begin{array}{c}\text { DO 2-rim } \\
\text { serpentinite }\end{array}$ & $\begin{array}{l}\text { DO 23-core } \\
\text { harzburgite }\end{array}$ & $\begin{array}{l}\text { DO 23-rim } \\
\text { serpentinite }\end{array}$ \\
\hline \multicolumn{7}{|l|}{ wt.\% } \\
\hline $\mathrm{SiO}_{2}$ & 39.41 & 40.62 & 40.94 & 40.48 & 39.46 & 40.35 \\
\hline $\mathrm{TiO}_{2}$ & 0.02 & 0.02 & 0.03 & 0.03 & 0.02 & 0.03 \\
\hline $\mathrm{Al}_{2} \mathrm{O}_{3}$ & 1.51 & 1.78 & 1.49 & 1.53 & 1.44 & 1.66 \\
\hline $\mathrm{Fe}_{2} \mathrm{O}_{3}$ & 7.51 & 3.63 & 7.44 & 3.63 & 7.22 & 3.60 \\
\hline $\mathrm{MnO}$ & 0.17 & 0.12 & 0.17 & 0.12 & 0.18 & 0.14 \\
\hline $\mathrm{MgO}$ & 37.89 & 40.01 & 39.44 & 40.02 & 38.24 & 40.52 \\
\hline $\mathrm{CaO}$ & 1.22 & 0.12 & 2.02 & 0.38 & 1.22 & 0.08 \\
\hline $\mathrm{Na}_{2} \mathrm{O}$ & 0.04 & 0.03 & 0.05 & 0.05 & 0.04 & 0.03 \\
\hline $\mathrm{K}_{2} \mathrm{O}$ & 0.003 & 0.002 & 0.006 & 0.001 & 0.004 & 0.001 \\
\hline $\mathrm{P}_{2} \mathrm{O}_{5}$ & 0.007 & 0.010 & 0.004 & 0.015 & 0.009 & 0.011 \\
\hline $\mathrm{Cr}_{2} \mathrm{O}_{3}$ & 0.34 & 0.47 & 0.37 & 0.41 & 0.32 & 0.37 \\
\hline $\mathrm{NiO}$ & 0.23 & 0.29 & 0.25 & 0.28 & 0.24 & 0.27 \\
\hline LOI & 12.00 & 13.10 & 8.10 & 13.40 & 12.30 & 13.40 \\
\hline Total & 100.39 & 100.19 & 100.32 & 100.32 & 100.66 & 100.43 \\
\hline \multicolumn{7}{|l|}{ ppm } \\
\hline $\mathrm{Sc}$ & 11 & 8 & 10 & 9 & 10 & 12 \\
\hline V & 64 & 55 & 54 & 49 & 58 & 57 \\
\hline $\mathrm{Cr}$ & 2622 & 3695 & 2758 & 3227 & 2507 & 2937 \\
\hline $\mathrm{Ni}$ & 2071 & 2590 & 2152 & 2511 & 2146 & 2442 \\
\hline Co & 101 & 68 & 104 & 50 & 99 & 49 \\
\hline $\mathrm{Li}$ & 3.41 & 1.53 & 2.58 & 1.26 & 2.83 & 1.02 \\
\hline $\mathrm{Rb}$ & 0.33 & 0.27 & 0.38 & 0.15 & 0.25 & 0.25 \\
\hline $\mathrm{Sr}$ & 7.68 & 6.26 & 7.17 & 1.76 & 4.65 & 4.15 \\
\hline Y & 0.709 & 0.807 & 0.743 & 1.572 & 0.597 & 1.156 \\
\hline $\mathrm{Zr}$ & $<$ b.d.l. & $<$ b.d.l. & $<$ b.d.l. & 2.928 & 4.890 & $<$ b.d.l. \\
\hline $\mathrm{Nb}$ & 1.578 & 1.587 & 1.594 & 2.344 & 1.584 & 2.231 \\
\hline $\mathrm{Sb}$ & 2.060 & 1.001 & 0.288 & 2.008 & 5.162 & 1.615 \\
\hline Cs & 0.149 & 0.026 & 0.507 & 0.044 & 0.198 & 0.033 \\
\hline $\mathrm{Ba}$ & 24.172 & 3.769 & 153.162 & 13.533 & 16.040 & 3.799 \\
\hline $\mathrm{La}$ & 0.1604 & 0.5771 & 0.0749 & 1.8001 & 0.1907 & 0.4212 \\
\hline $\mathrm{Ce}$ & 0.1852 & 0.8994 & 0.1577 & 2.5815 & 0.2478 & 0.6151 \\
\hline $\operatorname{Pr}$ & 0.0020 & 0.0459 & 0.0028 & 0.2129 & 0.0094 & 0.0433 \\
\hline $\mathrm{Nd}$ & 0.0070 & 0.1362 & 0.0124 & 0.6627 & 0.0285 & 0.1459 \\
\hline $\mathrm{Sm}$ & 0.0156 & 0.0432 & 0.0184 & 0.1333 & 0.0132 & 0.0421 \\
\hline $\mathrm{Eu}$ & 0.0116 & 0.0097 & 0.0307 & 0.0411 & 0.0100 & 0.0157 \\
\hline Gd & 0.0434 & 0.0670 & 0.0519 & 0.1682 & 0.0347 & 0.0780 \\
\hline $\mathrm{Tb}$ & 0.0110 & 0.0129 & 0.0137 & 0.0305 & 0.0085 & 0.0188 \\
\hline Dy & 0.0968 & 0.0954 & 0.1015 & 0.2024 & 0.0763 & 0.1414 \\
\hline Ho & 0.0259 & 0.0242 & 0.0271 & 0.0499 & 0.0206 & 0.0391 \\
\hline Er & 0.0845 & 0.0814 & 0.0867 & 0.1567 & 0.0730 & 0.1319 \\
\hline $\mathrm{Tm}$ & 0.0146 & 0.0144 & 0.0150 & 0.0264 & 0.0123 & 0.0238 \\
\hline $\mathrm{Yb}$ & 0.1117 & 0.1134 & 0.1086 & 0.1977 & 0.0944 & 0.1754 \\
\hline $\mathrm{Lu}$ & 0.0189 & 0.0217 & 0.0184 & 0.0345 & 0.0166 & 0.0288 \\
\hline $\mathrm{Hf}$ & $<$ b.d.l. & 0.0799 & 0.0033 & 0.0813 & 0.0706 & 0.0563 \\
\hline $\mathrm{Ta}$ & $<$ b.d.l. & $<$ b.d.l. & $<$ b.d.l. & 0.0127 & 1.8438 & 0.0114 \\
\hline $\mathrm{Pb}$ & 0.700 & 0.709 & 0.511 & 0.456 & 0.692 & 0.562 \\
\hline Th & 0.0025 & 0.0918 & 0.0031 & 0.0061 & 0.0049 & 0.0059 \\
\hline $\mathrm{U}$ & 0.0036 & 0.7097 & 0.0023 & 0.3453 & 0.2228 & 2.3561 \\
\hline
\end{tabular}

LOI, loss on ignition; < b.d.l., below detection limit; Sc, V, Cr, Ni and Co measured by XRF, other trace elements by ICP-MS. Samples are composed of dark harzburgitic cores and greenish serpentinized (Prv-bearing) rims. 

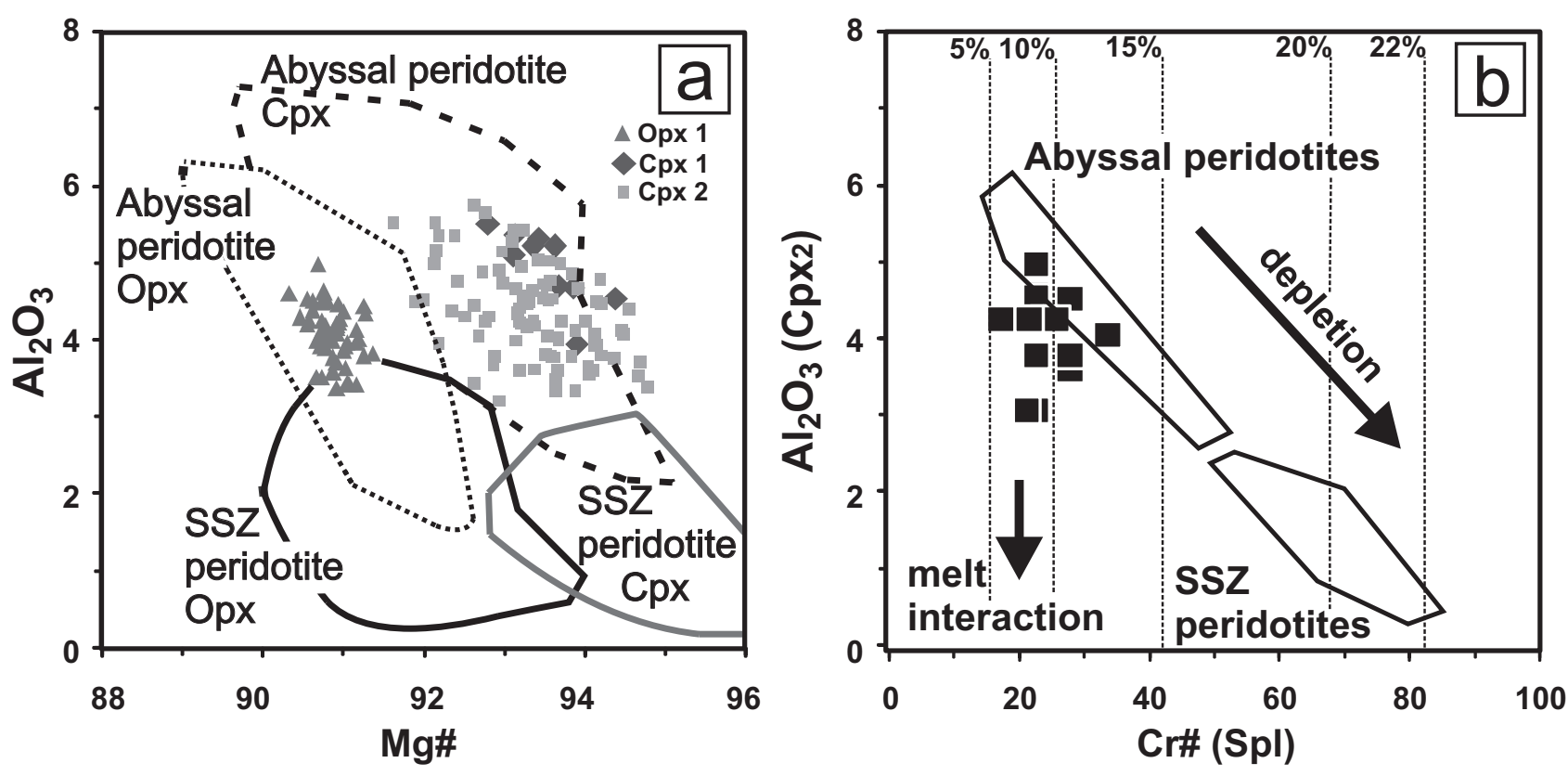

Fig. 6a - The $\mathrm{Al}_{2} \mathrm{O}_{3}-\mathrm{Mg} \#$ diagram of $\mathrm{Opx}_{1}, \mathrm{Cpx}_{1}$ and $\mathrm{Cpx}_{2}$ chemical compositions suggests an abyssal harzburgite (E1 event). After Choi et al. (2008). b - Chemical composition of $\mathrm{Cpx}_{2}-$ Spl pairs indicates batch (c. $10 \%$ ) melting of the upwelling Cpx harzburgite (E2 event). After Parkinson and Pearce (1998). SSZ - Supra-subduction zone.

for $1200^{\circ} \mathrm{C}$ or $13.6 \mathrm{kbar}$ for $1150^{\circ} \mathrm{C}$. For a temperature of $1100^{\circ} \mathrm{C}$, a pressure of $13.7 \mathrm{kbar}$ was calculated from Opx $_{1}-$ Cpx exsolution $_{(\text {in Opxl) }}$ lamellae (analyses no. 22 and 21 in Tab. 1). Alternatively, a pressure of $9.2 \mathrm{kbar}$ could be modelled for $1000^{\circ} \mathrm{C}$, or $6.9 \mathrm{kbar}$ for $950^{\circ} \mathrm{C}$ from the same mineral pair. For $1100^{\circ} \mathrm{C}$, a pressure of $10.3 \mathrm{kbar}$ was obtained from $\mathrm{Cpx}_{1}-\mathrm{Opx}$ exsolution (in $\mathrm{CpxI}$ lamellae pair (analyses no. 15 and 14 in Tab. 1). The pressure would drop to $5.8 \mathrm{kbar}$ at $1000^{\circ} \mathrm{C}$, or $3.5 \mathrm{kbar}$ at $950^{\circ} \mathrm{C}$ from the same mineral pair. Taken together, the estimated maximum $\mathrm{P}-\mathrm{T}$ conditions for the (early) E1 event could have been $1200-1300^{\circ} \mathrm{C} / 15-20 \mathrm{kbar}$.

\subsubsection{The E2 partial melting mantle event}

Subsolidus crystal-plastic deformation of the $\mathrm{Opx}_{1}$ $\left( \pm \mathrm{Cpx}_{1}\right)$ porphyroclasts and the different clinopyroxene $\left(\mathrm{Cpx}_{1}\right.$ vs. $\left.\mathrm{Cpx}_{2}\right)$ microstructures and chemical compositions (especially in $\mathrm{TiO}_{2}$ and $\mathrm{Al}_{2} \mathrm{O}_{3}$ contents, Tab. 1) of the incompletely solidified Spl harzburgite, could be interpreted as the result of crystallization induced by a temperature decrease, as the upwelling mantle most likely entered the base of the oceanic lithosphere. In regions where upwelling rates of the mantle were slow, a small amount $(\sim 2$ vol. $\%)$ of melt could have been present when e.g. abyssal peridotites entered the conductive regime at the base of the oceanic lithosphere (Seyler et al. 2001). Such a "residual" melt would be undersaturated in Opx, but could have precipitated Cpx, Al-rich and Ti-poor Spl, and sulphides (Seyler et al. 2001).
In our samples, aggregates of the late-magmatic $\mathrm{Cpx}_{2}$ with $\mathrm{Cr}-\mathrm{Spl}$ and scarce $\mathrm{Opx}_{2}$ occur as selvages around the kinked and sigmoidally rotated $\mathrm{Opx}_{1}$ porphyroclasts. Another higher-Al $\mathrm{Cpx}_{(3)}$ generation fills the fractures and axial plane cleavage of the kinked porphyroclasts. Both $\mathrm{Cpx}_{2}$ and $\mathrm{Cpx}_{3}$ represent (E2) late-magmatic or subsolidus stage of the studied harzburgites. The late-magmatic assemblage with $\mathrm{Cpx}_{2}$ appears to have crystallized from an interstitial melt during plastic deformation of the harzburgite. Such microstructures resemble melt-filled microfractures that form at the end of the crystallization of plutonic rocks (e.g. Bouchez et al. 1992), when the rheology is principally controlled by the interconnected (load-bearing) framework of crystals rather than by interconnected melt (Dell'Angelo and Tullis 1988).

The described "residual" melt was undersaturated in $\mathrm{Opx}_{(2)}$ but saturated in $\mathrm{Cpx}_{(2)}$ and low-Ti Spl. The experimental studies show that at pressures above $17 \mathrm{kbar}$, the melting reaction for $\mathrm{Spl}$ and Grt lherzolite produces liquids saturated in $\mathrm{Cpx}$ and $\mathrm{Spl}( \pm \mathrm{Ol})$ but not in Opx (Kinzler 1997). The interstitial liquid present in our harzburgitic rocks was therefore most likely produced within the upper pressure range of the Spl stability field during the $\mathrm{E} 2$ event. Indeed the chemical compositions of the $\mathrm{Cpx}_{2}-\mathrm{Spl}$ pairs (Fig. 6b) suggest formation of this interstitial liquid by c. 10 vol. \% partial or batch melting of the Cpx harzburgite during its slow upwelling close to the base of the oceanic lithosphere.

Any inferred increase in HREE and HFSE after a "refertilization" (infiltration of a Ca-enriched melt into the Ol-Opx rich crystal mush of incompletely solidified 

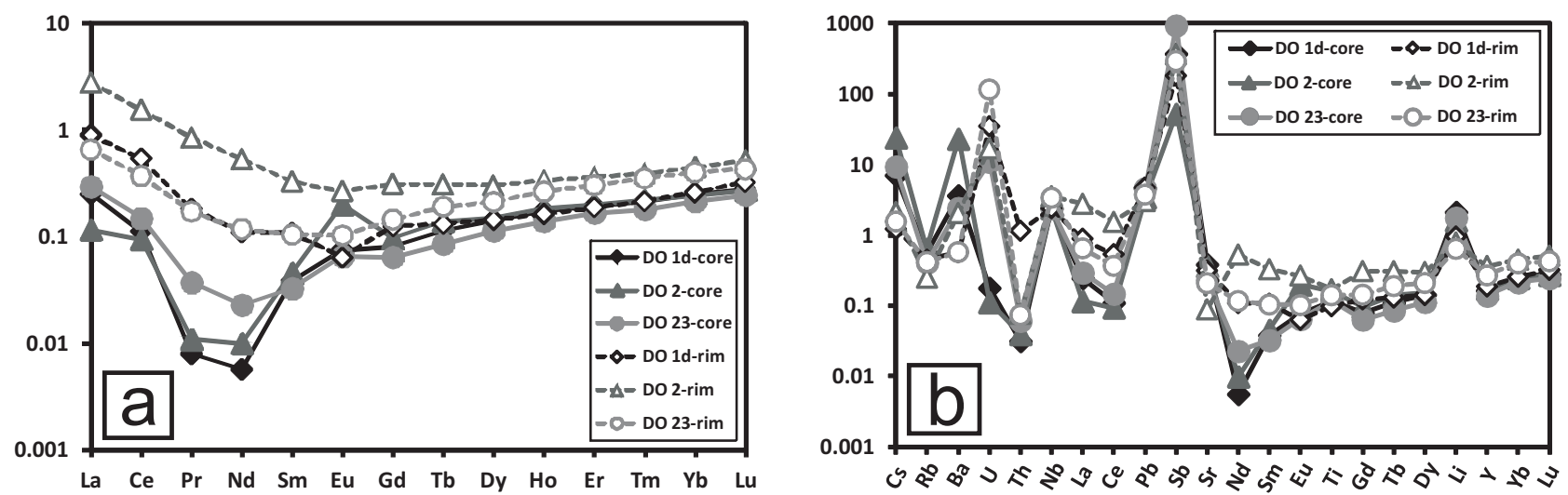

Fig. 7 Primitive Mantle-normalized patterns of harzburgites (normalization after McDonough and Sun 1995): a - The whole-rock REE patterns. b - The whole-rock trace-element patterns.

residual harzburgite, e.g. Brunelli et al. 2006; Le Roux et al. 2007; Jean et al. 2010) was not found in the studied Cpx harzburgite. Most of the $\mathrm{Cpx}_{1}$ should have undergone the batch partial melting during the $\mathrm{E} 2$ event and, on this basis, we speculate that the $\mathrm{Cpx}_{1}$ contents of our residual harzburgites were originally higher. This is, on the other hand, consistent with a relatively low degree of the E1 melting of a (lherzolitic?) protolith. Assumed additional, c. $10 \%$ (E2) remelting of the harzburgite (Fig. 6b) could not principally change only weakly depleted character of our Cpx harzburgites (Fig. 7a). The only exception represents the rare Cpx-rich harzburgite, probably indicating lower still degree of the E1 melting of a deeper mantle protolith if compared with the rest of our harzburgitic samples.

$\mathrm{P}-\mathrm{T}$ conditions of the $\mathrm{E} 2$ event were estimated using two-pyroxene-based thermometers after Putirka (2008). The pressure estimates depend on the assumed temperature input. For a temperature of $1100^{\circ} \mathrm{C}$, a pressure of 14.3 kbar was calculated from $\mathrm{Cpx}_{2}-\mathrm{Opx}_{2}$ pair (analyses no. 15 and 19 in Tab. 1). Similarly, a pressure of 9.8 kbar was found for the temperature of $1000^{\circ} \mathrm{C}$ from the same pair. For a temperature of $1000^{\circ} \mathrm{C}$, a pressure of 8.8 kbar was estimated from $\mathrm{Cpx}_{2}-\mathrm{Opx}$ exsolution ${ }_{(\mathrm{in} \mathrm{Cpx} 2)}$ lamellae pair (analyses no. 60 and 61 in Tab. 1). Alternatively, for the temperature of $950^{\circ} \mathrm{C}$, the pressure would drop to $6.5 \mathrm{kbar}$ using the same mineral pair. The inferred pressure interval of the E2 event of 8-15 kbar is consistent with the Spl stability field (Klemme 2004). In summary, our estimated pressures for the E2 event could have been $7-14 \mathrm{kbar}$ for a temperature interval of $950-1100^{\circ} \mathrm{C}$.

\subsubsection{The E3 and E4 metamorphic-metaso- matic events}

The Late Jurassic subduction of the back-arc basin oceanic crust and the underlying mantle culminated in blueschist-facies metamorphism (E3 event at 350$460^{\circ} \mathrm{C} / 10-12$ kbar, Faryad and Henjes-Kunst 1997). ${ }^{40} \mathrm{Ar}-{ }^{39} \mathrm{Ar}$ ages of "phengitic" white mica from blueschists, ranging in main interval from 160 to $150 \mathrm{Ma}$ (Dallmeyer et al. 1996; Faryad and Henjes-Kunst 1997), dated the near peak metamorphic conditions. Cloudy lower $\mathrm{Al} \mathrm{Cpx}_{4}$, associated with $\mathrm{Prg}$ in reaction rims between the $\mathrm{Opx}_{1}$ and $\mathrm{Cpx}_{2}$, or antigorite replacing $\mathrm{Ol}$ in coronas, could have recorded the E3 HP metamorphic event in serpentinites.

Perovskite and/or Adr seem to be related to serpentinization and rodingitization during the exhumation of harzburgite fragments in subduction channel and their emplacement into subduction-accretionary wedge (E4 event). A wider interval of the estimated $\mathrm{P}-\mathrm{T}$ conditions of this event $\left(300-500^{\circ} \mathrm{C} / 5-15 \mathrm{kbar}\right.$, at 150 to $130 \mathrm{Ma}$ ?) could be indicated by transition from the blueschist- to greenschist-facies mineral assemblages in serpentinites (antigorite replaced by chrysotile and lizardite) and in associating retrogressed blueschists with the newly-formed Chl, Ep, Ab, and Carb.

Perovskite was relatively more resistant to progressing serpentinization than the hosting $\mathrm{Opx}_{1}$ porphyroclasts. Despite the instability of Prv to pervasive $\mathrm{H}_{2} \mathrm{O}-\mathrm{CO}_{2}$-rich fluids at lower temperatures (Nesbitt et al. 1981), this mineral is well preserved in serpentinized $\mathrm{Opx}_{1}$ porphyroclasts. It is however usually missing in greenish-yellow to yellowish rodingitized domains crosscutting the serpentinites. There, the interaction between the fluid and Prv obviously involved a strong leaching of $\mathrm{Ca}^{2+}$ from the Prv structure into an aqueous fluid, leading to Prv dissolution. Mitchell and Chakhmouradian (1998) described a replacement of Prv by Adr. Although an evidence for such a reaction was not observed from common serpentinite samples, one cannot exclude that at least part of Tirich Adr formed there at the expense of Prv (e.g. Fig. 5a). However, our newly-found samples from Chl-rich 
veins in rodingites, containing Prv rimmed by Ti-rich Adr halos and surrounded by common Adr (Fig. 5c-d), undoubtedly confirm this replacement. Now it is clear that much of the Ti-rich Adr most likely formed at the expense of Prv.

The late generation of Ti-poor and Cr-rich Adr often fills fissures or forms $0.5-3 \mathrm{~cm}$ thick veins especially in rodingitized domains of serpentinites. This Adr mainly replaces clinopyroxenes, possibly Ti-rich Adr and/or Prv.

Typical serpentinite of the E4 event is composed of Srp, Chl, Act to Hbl, Pph, Qz, Cr-Fe Spl, Mag and $\mathrm{Hem} \pm$ Carb with Tlc. The presence of pyrophanite $\left(\mathrm{MnTiO}_{3}\right)$ alteration rims on Prv crystals and the formation of the $\mathrm{Cr}-\mathrm{Fe}-\mathrm{Spl}$ to $\mathrm{Cr}-\mathrm{Mag}$ is compatible with an increased $\mathrm{Mn}^{2+}$ and $\mathrm{Fe}^{2+}$ activity during the late stages of serpentinization. Oxides (Fe-Mn) and hydro-oxides, and hydration of the Spl harzburgite with the $\mathrm{H}_{2} \mathrm{O}-\mathrm{CO}_{2}$ and $\mathrm{Si}-\mathrm{Fe}-\mathrm{Mn}$-rich fluids are therefore related to final stage (late E4 event) of serpentinization, combined with rodingitization.

\subsection{Definition of chemical changes in dark harzburgitic core and serpentinite rim}

Chemical variations between the presumed lherzolitic protolith of "pyrolite" (McDonough and Sun 1995) composition and the studied dark harzburgitic core reflect two-stage melting (E1 and E2) events during the Cpx harzburgite formation. However, the pervasive metamorphic fluids penetrated also into the dark harzburgitic cores during serpentinization (E3 and E4 events). The best evidence is the presence of metamorphic phases as $\mathrm{Cpx}_{4,5}, \mathrm{Hbl}$ and $\mathrm{Srp}$ (Atg, or Ctl, Lz) in these cores, however limited.

For the reconstruction of a mechanism and geodynamic setting of serpentinization (e.g. Kodolányi et al. 2012), we attempted to constrain a pristine chemical character of the studied Cpx harzburgite from the rarely preserved dark cores of the serpentinite boulders. We were in particular interested in deciphering the mineralogical and chemical changes during the low-degree partial melting (E1 and E2 events). For this purpose we compared the pristine harzburgite with the recommended "pyrolite" composition (after McDonough and Sun 1995). We also examined effects of fluid-rock interaction(s) (E3 and E4 events) by comparison of chemical compositions of Cpx harzburgite in the dark core (only weakly affected by serpentinization) and its serpentinite rim.

\subsubsection{Chemical changes between "pyrolite" and the dark Cpx harzburgite cores}

The changes which could have occurred between the chemical composition of an ideal "pyrolite" and the dark
Cpx harzburgite core are best seen from the Primitive Mantle-normalized spiderplot (Fig. 7b), even though the part of the trace-element signature of the most mobile elements was obscured by subsequent metamorphic events.

The LILE in core samples display various and relatively high enrichments in Cs $(\sim 7-24 \times)$ and $\mathrm{Ba}(\sim 2-23 \times)$ beside depleted Rb and Sr. HFSE and REE contents show overall depletions, however $\mathrm{Nb}$ is slightly $(\sim 2.4 \times)$ and Sb extremely $(\sim 50-940 \times)$ enriched. Moreover, sample DO 23 -core is also significantly enriched in $U(\sim 11 \times)$ and $\mathrm{Ta}(\sim 50 \times)$.

The relative decrease in REE can be explained by extraction of a melt from a (harzburgitic) residue (E1 event). Low-degree batch melting (E2 event) could not influence the REE (especially the HREE) and HFSE contents sufficiently. An increased content in $\mathrm{Cs}$ and $\mathrm{Ba}$ is usually interpreted as an impact of slab-derived (metamorphic) fluids (Scambelluri et al. 2004; Khedr and Arai 2009). Therefore these signatures in the studied samples should be the result of the E3 and E4 events.

\subsubsection{Chemical changes between the harzburgitic cores and serpentinized rims}

The chemical changes between a dark harzburgitic core and a serpentinized rim could reflect the two E3 and E4 fluid-rock interactions, depending on conditions when trace elements became mobile in a fluid phase. It is obvious that the latest stages of (E4) serpentinization and rodingitization left a strong impact on the chemical composition mainly in serpentinized rim of the dark harzburgitic cores. The following chemical changes are observable between the dark Cpx harzburgite core and a serpentinized rim around this core.

No depletion (or a negligible change) exhibit $\mathrm{Ti}, \mathrm{Pb}$ and Sc. The LILE from serpentinites (rim samples) display significant decrease in $\mathrm{Cs}$ and $\mathrm{Ba}(\sim 4-11 \times)$. Among HFSE, characteristic are relative depletion in $\mathrm{Sb}(\sim 2-3 \times)$, slight enrichment in $\mathrm{Nb}(\sim 1.3 \times)$ and significant enrichment in $U(\sim 10-200 \times)$ compared with the core equivalents. Additionally, sample DO 2-rim shows an increase in $\mathrm{Sb}(\sim 7 \times)$ and DO 1d-rim in Th $(\sim 40 \times)$. LREE display a distinct enrichment (La and $\mathrm{Ce}: \sim 7 \times, \mathrm{Pr}$ and $\mathrm{Nd}: \sim 20 \times$, Sm: $\sim 5 \times)$. All HREE are weakly depleted $(\sim 1.3-2.5 \times)$ within serpentinites. Lithium exhibits relatively decreased contents $(\sim 2-3 \times)$, while $\mathrm{Cr}$ and $\mathrm{Ni}$ are slightly increased $(\sim 1.25 \times)$.

The previous review of the chemical changes is a good evidence for a relative stability of HREE to pervading fluids. The negligible changes were detected in HFSE elements ( $\mathrm{Ti}$ and $\mathrm{Nb}$ ); $\mathrm{Sc}$ and $\mathrm{Pb}$ behaved similarly. Only slight changes were also shown by $\mathrm{Cr}$ and $\mathrm{Ni}$. On 
the other hand, the enrichment of the most LILE (Li, Cs, and $\mathrm{Ba}$ ), Th, U, LREE and $\mathrm{Sb}$ from pervading fluids was characteristic.

\section{Discussion}

\subsection{Geodynamic setting of serpentinization}

Based on in situ study, Kodolányi et al. (2012) proposed criteria distinguishing the serpentinites formed in midocean ridge, fore-arc and passive margin settings, on the basis of trace elements. In general, bulk serpentinites showed up to several orders of magnitude enriched $\mathrm{Cl}$, $\mathrm{B}, \mathrm{Sr}, \mathrm{U}, \mathrm{Sb}, \mathrm{Pb}, \mathrm{Rb}, \mathrm{Cs}$ and Li relative to elements of similar compatibility during mantle melting. Also the LREE enrichment and the appearance of positive Eu anomaly can be often related to serpentinization. These elements are largely hosted in serpentine (lizardite and chrysotile, but not antigorite). However, the magnitude of such enrichments often depends on the geodynamic setting.

The mid-ocean ridge serpentinites are enriched in $\mathrm{B}$, $\mathrm{U}, \mathrm{Pb}, \mathrm{Sb}, \mathrm{Sr}, \mathrm{Li}, \pm \mathrm{As}$. They also exhibit positive $\mathrm{Eu}$ anomaly on chondrite-normalized REE plots. Primitive Mantle-normalized multielement diagrams display Ushaped patterns. Acidic fluids, like those emanating from mid-ocean ridge hydrothermal systems, have increased LREE/HREE ratios and positive Eu anomalies, but overall low REE contents.

The fore-arc serpentinites are characterized by low incompatible trace-element contents, the lowest $\mathrm{Cl}$ as well as the highest $\mathrm{Rb}, \mathrm{Cs}$ and $\mathrm{Sr}$ enrichments, but lack the $\mathrm{U}$ enrichment commonly observed in MOR and passivemargin serpentinites. On the other hand, passive-margin serpentinites show the highest $\mathrm{B}$ contents and prominent $\mathrm{U}$ enrichment, and overall high REE concentrations.

Scambelluri et al. (2004) with Khedr and Arai (2009), illustrated increasing $\mathrm{Sr}$ from serpentinized oceanic peridotite to HP antigorite peridotite. Olivine-, Opxand $\mathrm{Cpx}$-bearing metaperidotites displayed enrichment in $\mathrm{B}, \mathrm{Rb}, \mathrm{Sr}, \mathrm{Cs}, \mathrm{Ba}, \mathrm{Li}$, compared to the HFSE. They characterized subduction-zone metasomatism in hydrated peridotites as showing U-shaped REE patterns and enrichment in LILE $(\mathrm{Cs}, \mathrm{Pb}$ and $\mathrm{Ba}$ ) relative to HFSE (Hf, Ta, Zr and Nb) and Th. Such characteristics are consistent with the mantle metasomatism by slab-derived fluids either in subduction channel, or in overlying mantle wedge.

Our chemical data (Tab. 2, Fig. 7) suggest the mobility most of the LILE (Th, U, Rb, Sr, Cs, Ba, in part Pb) and LREE, which was likely related to pervading fluids during the E3 to E4 events. In general, LILE and LREE show relative enrichment to HFSE and HREE. Part of the LILE shows an increase (Th, U, Cs and Ba), but the rest suffered a decrease ( $\mathrm{Rb}$ and $\mathrm{Sr}$ ) after serpentinization and/or rodingitization. Uranium, $\mathrm{Sb}$ and $\mathrm{Li}$ exhibit positive anomalies. Similarly, Cs and Ba show positive anomalies in a spider diagram (Fig. 7b), interpretable as a consequence of slab-derived metamorphic fluids. The LREE display a U-shaped pattern. Our samples, enriched in $\mathrm{Cs}, \mathrm{Ba}, \mathrm{U}, \mathrm{Pb}, \mathrm{Sb}$ and $\mathrm{Li}$ (Fig. 7b) can therefore be interpreted as having been overprinted by slab-derived (metamorphic) fluids. The blueschist-facies metamorphic rocks were their most likely source.

\subsection{Perovskite and andradite genesis}

Perovskite usually occurs in a restricted zone, which could be characterized as a serpentinization front or a reaction zone between the progressive serpentinization front and the original Cpx harzburgite of the dark core. The main reacting phase of the $\mathrm{Cpx}$ harzburgite was $\mathrm{Opx}_{1}$ attacked by $\mathrm{CO}_{2}$-rich aqueous (serpentinization) fluids transporting $\mathrm{Ca}, \mathrm{Ti}, \mathrm{Fe}$ and LREE from a subducted slab, partitioned into Prv at fairly low Si activity. This indicates post-magmatic, reaction-metasomatic origin of the Prv. On the other hand, the probability of Prv formation due to a melt-rock interaction (during the E2 event) was low. Perovskite does not occur in the preserved (not serpentinized) Opx ${ }_{1}$ porphyroclasts surrounded by the (E2) $\mathrm{Cpx}_{2}$ aggregates in the dark harzburgitic cores.

The E3 event of HP subduction generated the slabderived fluids, which could have pervaded through the exhuming metaultramafic fragments in subduction channel also during the later E4 event.

Crystallization of Prv was highly improbable during the final stage of exhumation within an accretionary wedge (late-stage of the E4 event), because of chemical composition of metamorphic fluids ( $\mathrm{Si}-\mathrm{Fe}-\mathrm{Mn}-\mathrm{rich}$ ), unsuitable for the Prv nucleation. On the contrary, Prv was replaced by Pph and partly dissolved by rodingitization fluids. However, an earlier stage of the E4 event seems to be the appropriate for the likely Prv genesis. Perovskite might therefore form during exhumation of harzburgitic fragments in subduction channel or during a subsequent burial within the frontal (subduction-) accretion wedge. Pervading $\mathrm{CO}_{2}$-rich aqueous fluids (transporting $\mathrm{Ca}$, Ti, Fe and LREE) might partly dissolve and destabilize the $\mathrm{Opx}_{1}$ porphyroclasts (Fig. 2a-b) and thus initiate the Prv growth along and at the expense of the Cpx exsolution lamellae (Figs 3, 5). Calcium, titanium and LREE (La, Ce) from slab-derived fluids might reside in Prv during exhumation serpentinization.

The inferred Opx breakdown/dissolution reaction (E4 event) is: $(\mathrm{Mg}, \mathrm{Fe}, \mathrm{Ca})(\mathrm{Mg}, \mathrm{Fe}, \mathrm{Al})(\mathrm{Si}, \mathrm{Al})_{2} \mathrm{O}_{6}(\mathrm{Opx}$ with high-Al and higher-Ti $\mathrm{Cpx}$ exsolution lamellae) + $\operatorname{LREE}(\mathrm{La}, \mathrm{Ce})$ bearing $\mathrm{Cpx}_{1-3}+\left(\mathrm{CO}_{2}\right)_{\mathrm{aq}}+\mathrm{H}_{2} \mathrm{O}_{(\mathrm{P}, \mathrm{F}, \mathrm{Cl}, \mathrm{La}, \mathrm{Ce})}+$ 
$\mathrm{Ca}^{2+}+\mathrm{Ti} / \mathrm{Fe}^{3+}=(\mathrm{La}, \mathrm{Ce}) \mathrm{CaTiO}_{3}(\mathrm{Prv})$ and/or Ti-rich Adr $+\mathrm{Ap}+\mathrm{Di}+\mathrm{Srp}+\mathrm{Carb}+\mathrm{Qz}$.

Activities of Ca were likely high, and of Si fairly low, to replace Cpx lamellae in $\mathrm{Opx}_{1}$ by Prv. Narrow association of Prv with other Ca-(Ti) rich phases (Adr, Ap, Di, Ves and Carb) indicates that both serpentinization and rodingitization processes initiated the breakdown of the $\mathrm{Opx}_{1}$ porphyroclasts. The exsolved Cpx lamellae were the main source of the Prv and/or Adr growth in the $\mathrm{Opx}_{1}$ porphyroclasts due to acting $\mathrm{CO}_{2}$-rich aqueous fluids obviously released from marbles in subduction channel or within an accretion wedge. Presence of Ap demonstrates that $\mathrm{P}$ with $\mathrm{F}$ were important components of the fluid phase. The textural relationships indicate that the formation of the Ap was linked to the crystallization of the hydrous minerals (Ap enclosed in Chl aggregates).

Most likely, a decreased oxygen fugacity and increased $\mathrm{Ca}-\mathrm{Si}$ activity in rodingitization fluids caused the change from Prv to Adr crystallization. Low oxygen fugacity supports the stability of Ti-rich Adr (Müntener and Hermann 1994). The presence of Prv and Ti-rich Adr in the same thin-section (e.g. sample DO-2f-2, Fig. 5a, and those two newly-found samples), on the other hand, clearly indicates such changes in activities of $\mathrm{Si}, \mathrm{Ti}$, and oxygen fugacity as well, especially in transition zones between serpentinization (Prv present) and rodingitization (Prv missing).

The inferred fluid-enhanced origin of the Prv crystals is consistent with their variable size, shape and irregular individual or a group (up to 25 Prv grains occur in one $\mathrm{Opx}_{1}$ porphyroclast, or to about 80 grains in one thin section) distribution of Prv within the partly to totally serpentinized $\mathrm{Opx}_{1}$ porphyroclasts. Enrichment of pervading fluids in sulphur is inferred from millerite (NiS) inclusions in Prv (Fig. 3a).

Perovskite formation seems to be postdating the subduction-metamorphic (E3) event. Relatively fresh appearance of Prv after serpentinization (E3 to E4 event) supports this genetic model. Progressive rodingitization within serpentinites (late E4 event) obscured the whole domain of the Prv distribution in original Cpx harzburgites. The older perovskite generation is preserved in $\mathrm{Opx}_{1}$ porphyroclasts, indicating relatively weak effect of both serpentinization and rodingitization around the well preserved dark cores of the original Cpx harzburgites in serpentinites. However, a newer generation of skeletal to vein-type $\operatorname{Prv}(2)$, discovered from Chl-rich veins directly in rodingites, is usually partly to almost totally replaced by Ti-rich Adr halos and surrounded by common (Ti-poor) Adr.

\subsection{The age of the $E 1$ to $E 4$ events}

Although the age of the E1 event (300-250 Ma?) is not constrained by radiometric dating on the mantle rocks, the timing of continental crust extension at the margin of the Meliata Basin is well defined by the ages of S- and A-type Permian granites (Putiš et al. 2000; Radvanec et al. 2009b) as well as calc-alkaline and A-type volcanites (Kotov et al. 1996; Vozárová et al. 2009). The magmatism is an indicator that the crust, with the underlying mantle lithosphere, could have been melted due to extension above a subduction zone, and, after delamination, during the riftogenesis (Fig. 8). This is consistent with the northwest-ward (in present-day geographic co-ordinates) subduction of the Paleotethyan ocenic crust below the Intra-Alpine terrain (Stampfli 1996). The batch melting (E2 event) could, on the other hand, reflect mantle environment below a slowly spreading ridge related to evolving oceanic crust of the Meliata Basin. The proposed age for the E2 event (250-200 Ma?) is thus compatible with the opening and growth of the Melita Oceanic Basin in Triassic times that is well constrained also by lithostratigraphical data from sedimentary sequences (Mock et al. 1998).

The E3 event was dated by ${ }^{40} \mathrm{Ar}-{ }^{39} \mathrm{Ar}$ ages of "phengitic" white mica from blueschists (Dallmeyer et al. 1996; Faryad and Henjes-Kunst 1997), falling mainly within the time interval of 160-150 Ma. The age of the E4 event is thus constrained at 150-130 Ma, because from c. 130 Ma to $c .100 \mathrm{Ma}$ the Meliatic nappes were thrusting onto the West-Carpathian orogenic wedge - compressed former passive continental margin of the Meliata Oceanic Basin. This thrusting within the orogenic wedge is well constrained by ${ }^{40} \mathrm{Ar}-{ }^{39} \mathrm{Ar}$ ages of white micas from the shear zones (Putiš et al. 2008, 2009). The Meliatic subduction-accretionary wedge (Putiš et al. 2011b) must have formed between $c$. 150 and $130 \mathrm{Ma}$. The age of the perovskite and/or andradite is therefore supposed to be overlapping with the age of the E4 event.

\section{Conclusions}

The studied slightly depleted Cpx harzburgites from Dobšiná document rather complex evolution history of the mantle fragments incorporated into the Meliata tectonic Unit in the Slovak part of the Western Carpathians. The Cpx harzburgite most likely represents an abyssal peridotite related to evolving oceanic crust of the Neotethyan Meliata Oceanic back-arc Basin. The following evolution events (E1 to E4) have been distinguished.

The early magmatic E1 event (1 200-1 $300^{\circ} \mathrm{C} / 15-20$ kbar, at 300-250 Ma?) mineral assemblage of $\mathrm{Ol}, \mathrm{Opx}_{1}$, $\mathrm{Cr}-\mathrm{Spl}, \pm \mathrm{Cpx}_{1}$ formed during the early stage of mantle upwelling and c. 15-20\% adiabatic melting of a lherzolitic(?) precursor, resulting from decompression of the mantle beneath a spreading (Neotethyan, Meliatic) ridge.

Subsolidus or submagmatic deformation (E2 event, 900-1 $000{ }^{\circ} \mathrm{C} / 5-10 \mathrm{kbar}$, at $250-200 \mathrm{Ma}$ ?) of incom- 
SE
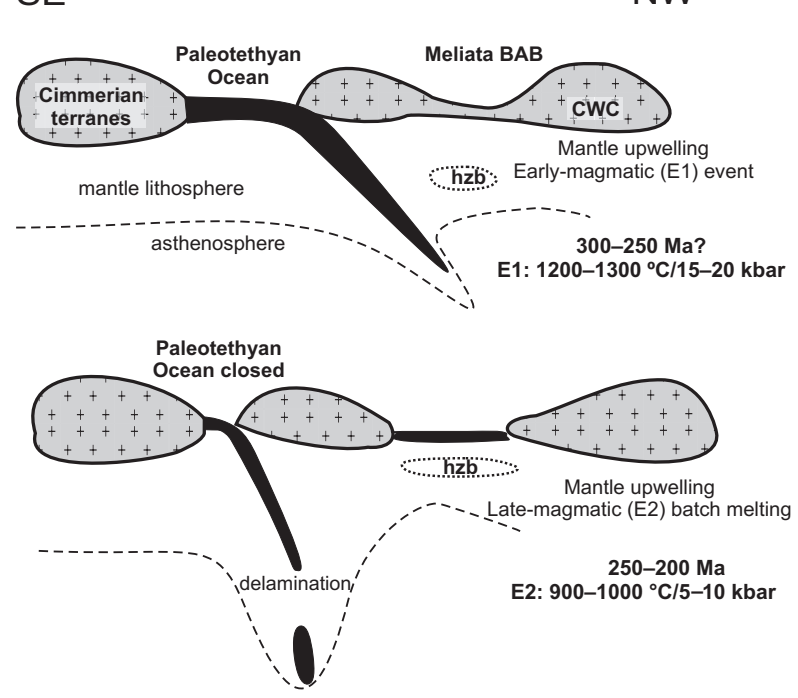

E3: Closing of the Meliata BAB and subduction of oceanic crust: 200-150 Ma

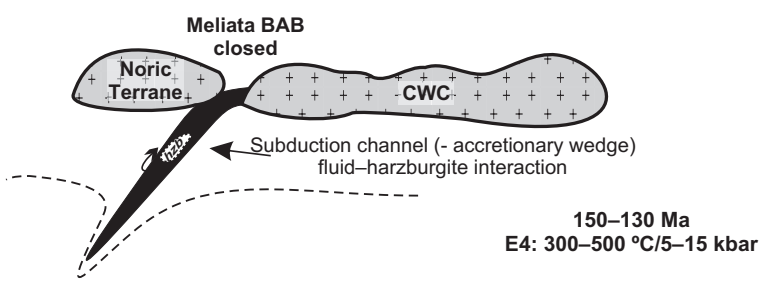

Fig. 8 Idealized evolution scheme of the Neotethyan, Meliata Back-arc Basin crust-mantle (E1-E2) and subduction channel-accretionary wedge (E3-E4) events deciphered from serpentinized Spl harzburgites (Dobšiná, Slovakia, the Meliata Unit). hzb $=\mathrm{Spl}$ harzburgite; $\mathrm{BAB}=$ back-arc basin; $\mathrm{CWC}=$ Central Western Carpathians.

pletely solidified harzburgite, forming the $\mathrm{Opx}_{1} / \mathrm{Cpx}$ porphyroclasts, was accompanied by partial melting and crystallization of $\mathrm{Cpx}_{2}, \mathrm{Cr}-\mathrm{Spl}$, and rare $\mathrm{Opx}_{2}$ around the HT deformed, rotated and kinked $\mathrm{Opx}_{1} / \mathrm{Cpx}_{1}$ porphyroclasts. The E2 event indicates that the second stage of c. $10 \%$ batch melting occurred within slowly upwelling mantle.

The perovskite and/or andradite formation seems to be postdating the subduction metamorphism (E3 event, dated at 160 to $150 \mathrm{Ma}$, according to published ${ }^{40} \mathrm{Ar}-{ }^{39} \mathrm{Ar}$ ages of "phengitic" white mica from associating blueschists). Formation of cloudy lower $\mathrm{Al} \mathrm{Cpx}_{4}$ with $\mathrm{Prg}$ or $\mathrm{Mg}-\mathrm{Hbl}$ in reaction rims between the $\mathrm{Opx}_{1}$ and $\mathrm{Cpx}_{2}$, or antigorite replacing $\mathrm{Ol}$, could have recorded the E3 HP metamorphic event.

The harzburgite fragments might have undergone serpentinization and rodingitization during the exhumation in subduction channel and/or during formation of an accretionary wedge (E4 event at $300-500^{\circ} \mathrm{C} / 5-15$ $\mathrm{kbar}$, at 150 to $130 \mathrm{Ma}$ ?) due to pervading slab-derived aqueous fluids rich in $\mathrm{CO}_{2}$, transporting $\mathrm{Ca}$, Ti, $\mathrm{Fe}$, LREE partitioned into Prv. The sources of such fluids might have been the blueschist- to greenschist-facies rocks from subduction channel and/or a mélange type subduction-accretionary wedge. The bulk-rock enrichment in LREE, $\mathrm{Cs}, \mathrm{Ba}, \mathrm{U}, \mathrm{Pb}, \mathrm{Sb}$ and $\mathrm{Li}$ seems to be an effect of the metamorphic (mostly slab-derived) fluids. The late-metamorphic $\mathrm{H}_{2} \mathrm{O}-\mathrm{CO}_{2} / \mathrm{Si}-\mathrm{Fe}-\mathrm{Mn}$-rich fluids caused replacement of Prv by pyrophanite and crystallization of Ti-rich and/or Ti-poor Adr aggregates at the expense of Cpx and/or Prv during final stage of serpentinization combined with rodingitization.

Acknowledgements. This work was supported by the APVV-0081-10 and VEGA-1/0255/11 scientific grants. We thank M. Radvanec for field co-operation, I. Holický and D. Ozdín for EMP analyses, P. Nagl for XRF analyses, T. Meisel for ICP MS analyses, M. Hain for XR-tomography, R. Marshall for reviewing the English content, P. Jeřábek and L. Ackerman (Prague) for their constructive suggestions, and V. Janoušek (Journal of Geosciences editor) for helpful editorial guidance. The paper benefited from discussions with K. Ye (Beijing).

Electronic supplementary material. The measurements of the standard material MUH (= Montan University Harzburgite from Kraubath) are available online at the Journal web site $w w w$.jgeosci.org.

\section{References}

Biely A, Bezák V, Eleč́o M, Gross P, Kaličiak M, Konečný V, Lexa J, Mello J, NemČok J, Potfaj M, Rakús M, Vass D, Vozár J, VozÁrová A (1996) Geological map of Slovakia, 1:500 000. State Geological Institute of Dionýz Štúr Publishers, Bratislava

Bodinier J-L, Godard M (2007) Orogenic, Ophiolitic, and Abyssal Peridotites: In: CARLSON RW (ed) Treatise on Geochemistry. Vol. 2. Elsevier, Amsterdam, pp 1-73

Bouchez J-L, Dela C, Gleizes G, Nédélec A, Cuney M (1992) Submagmatic microfractures in granites. Geology 20: $35-38$

Brunelli D, Seyler M, Cipriani A, Ottolini L, Bonatti E (2006) Discontinuous melt extraction and weak refertilization of mantle peridotites at the Vema lithospheric section (Mid-Atlantic Ridge). J Petrol 47: 745-771

Burnham M, Meisel T, Kriete C (2010) OKUM and MUH-1: two new IAG-certified ultramafic rock reference materials. Geochim Cosmochim Acta 74, Suppl 1: A129

Chakhmouradian AR, Mitchell RH (1997) Compositional variation of perovskite-group minerals from the carbonatite complexes of the Kola alkaline Province, Russia. Canad Mineral 35: 1293-1310 
Chakhmouradian AR, Mitchell RH (2000) Occurrence, alteration patterns, and compositional variation of perovskite in kimberlites. Canad Mineral 38: 975-994

Choi SH, Shervais JW, Mukasa SB (2008) Supra-subduction and abyssal mantle peridotites of the Coast Range ophiolite, California. Contrib Mineral Petrol 156: $551-576$

Currie KL (1975) The geology and petrology of the Ice River alkaline complex, British Columbia. Geol Surv Canada Bull 245: 1-68

Dallmeyer RD, Neubauer F, Handler R, Fritz H, Müller W, Pana D, Putiš M (1996) Tectonothermal evolution of the internal Alps and Carpathians: evidence from ${ }^{40} \mathrm{Ar} /{ }^{39} \mathrm{Ar}$ mineral and whole-rock data. Eclogae Geol Helv 89: 203-227

Dal Piaz GV, Martin S, Villa I, Gosso G, Marschalko R (1995) Late Jurassic blueschist facies pebbles from the western Carpathian orogenic wedge and palaeostructural implications for western Tethys evolution. Tectonics 14: 874-885

Dell'Angelo LN, Tullis J (1988) Experimental deformation of partially melted granitic aggregates. J Metamorph Geol 6: 495-515

Droop GTR (1987) A general equation for estimating $\mathrm{Fe}^{3+}$ concentrations in ferromagnesian silicates and oxides from microprobe analyses, using stoichiometric criteria. Mineral Mag 51: 431-435

Faryad SW, HenJes-Kunst F (1997) Petrological and K-Ar and ${ }^{40} \mathrm{Ar}-{ }^{39} \mathrm{Ar}$ age constraints for the tectonothermal evolution of the high-pressure Meliata unit, Western Carpathians (Slovakia). Tectonophysics 280: 141-156

Faryad SW, Spišiak J, Horváth P, Hovorka D, DianišKa I, Jósza S (2005) Petrological and geochemical features of the Meliata mafic rocks from the sutured Triassic oceanic basin, Western Carpathians. Ofioliti 30: 27-35

Fediuková E, Hovorka D, Greguš J (1976) Compositional zoning of andradite from serpentinite at Dobšiná (West Carpathians). Věst Ústř Úst Geol 51: 339-345

GIERÉ R (1990) Hydrothermal mobility of Ti, Zr and REE: examples from the Bergell and Adamello contact aureoles (Italy). Terra Nova 2: 60-67

Grégoire M, McInNes BIA, O’ReIlly SY (2001) Hydrous metasomatism of oceanic sub-arc mantle, Lihir, Papua New Guinea: Part 2. Trace element characteristics of slab-derived fluids. Lithos 59: 91-108

Heaman LM, Kuarsgaard BA, Creaser RA (2003) The timing of kimberlite magmatism and implications for diamond exploration: a global perspective. Lithos 71: 153-184

Hovorka D, Jaroš J, Kratochvíl M, Mock R (1984) The Mesozoic ophiolites of the Western Carpathians. Krystalinikum 17: 143-157

Hovorka D, Ivan P, Jaroš J, Kratochvíl M, Reichwalder P, RoJKOVIČ I, SPIŠIAK J, TuRANOVÁ L (1985) Ultramafic rocks of the Western Carpathians, Czechoslovakia. Geological Institute of Dionýz Štúr Publishers, Bratislava, pp $1-258$

Ivan P (2002) Relics of the Meliata Ocean crust: geodynamic implications of mineralogical, petrological and geochemical proxies. Geol Carpath 53: 245-256

Jean MM, Shervais JW, Choi S-H, Mukasa SB (2010) Melt extraction and melt refertilization in mantle peridotite of the Coast Range ophiolite: an LA-ICP-MS study. Contrib Mineral Petrol 159: 113-136

Kelemen PB, Hirth G, Shimizu N, Spielgelman M, Dick HJB (1997) A review of melt migration processes in the adiabatically upwelling mantle beneath oceanic spreading ridges. Phil Trans Roy Soc London A355: 283-318

KHEDR MZ, ARAI S (2009) Geochemistry of metasomatized peridotites above subducting slab: a case study of hydrous metaperidotites from Happo-O'ne complex, central Japan. J Mineral Petrol Sci 104: 313-318

KINZLER RJ (1997) Melting of mantle peridotite at pressure approaching the spinel to garnet transition: application to mid-ocean-ridge basalt petrogenesis. J Geophys Res 102: $853-874$

KLemme S (2004) The influence of Cr on the garnet-spinel transition in the Earth's mantle: experiments in the system $\mathrm{MgO}-\mathrm{Cr}_{2} \mathrm{O}_{3}-\mathrm{SiO}_{2}$ and thermodynamic modelling. Lithos 77: 639-646

Kodolányi J, Pettke T, Spandler 1 C, Kamber BS, Gméling K (2012) Geochemistry of ocean floor and fore-arc serpentinites: constraints on the ultramafic input to subduction zones. J Petrol 53: 235-270

Kotov AB, Miko O, Putiš M, Korikovsky SP, SAL'Nikova EB, Kovach VP, Yakovleva S (1996) U-Pb dating of zircons of postorogenic acid metavolcanics and metasubvolcanics: a record of Permian-Triassic taphrogeny of the West-Carpathian basement. Geol Carpath 47: 73-79

Kozur H (1991) The evolution of the Meliata-Hallstatt Ocean and its significance for the early evolution of the Eastern Alps and Western Carpathians. Palaeogeogr Palaeoclim Palaeoec 87: 109-135

Kozur H, Mock R (1985) Erster Nachweis von Jura der Meliata-Einheit der südlichen Westkarpaten. Geol Paläont Mitt 13: 223-238

Kozur H, Mock R (1997) New paleogeographic and tectonic interpretations in the Slovakian Carpathians and their implications for correlations with the Eastern Alps and other parts of the Western Tethys, Part II: Inner Western Carpathians. Miner Slov 29: 164-209

Le Roux V, Bodinier J-L, Tommasi A, Alard O, Dautria J-M, VAuchez A, Riches AJV (2007) The Lherz spinel lherzolite: refertilized rather than pristine mantle. Earth Planet Sci Lett 259: 599-612

Malvoisin B, Chopin Ch, Brunet F, Galvez ME (2012) Low-temperature wollastonite formed by carbonate 
reduction: a marker of serpentinite redox conditions. J Petrol 53: 159-176

Marincea Ş, Dumitraş DG, Fransolet AM (2010) The association spurrite-perovskite in the inner exoskarn zone from Cornet Hill (Metaliferi Mountains, Romania). Acta Mineral-Petrogr, Abstr Ser 6: 433

McDonough WF, Sun S (1995) The composition of the Earth. Chem Geol 120: 223-253

Meisel T, Schöner N, Paliulionyte V, Kahr E (2002) Determination of rare earth elements (REE), $\mathrm{Y}, \mathrm{Th}, \mathrm{Zr}, \mathrm{Hf}$, $\mathrm{Nb}$ and $\mathrm{Ta}$ in geological reference materials G-2, G-3, SCo-1 and WGB-1 by sodium peroxide sintering and ICP-MS. Geostand Newsl 26: 53-61

Mitchell RH, CHAKHMOURADIAN AR (1998) Instability of perovskite in a $\mathrm{CO}_{2}$-rich environment: examples from carbonatite and kimberlite. Canad Mineral 36: 939-952

Mock R, SÝkora M, Aubrecht R, Ožvoldová L, Kronome B, Reichwalder P, Jablonský J (1998) Petrology and petrography of the Meliaticum near the Meliata and Jaklovce villages, Slovakia. Slovak Geol Mag 4: 223-260

Müntener O, Hermann J (1994) Titanian andradite in a metapyroxenite layer from the Malenco ultramafics (Italy): implications for Ti-mobility and low oxygen fugacity. Contrib Mineral Petrol 156: 156-168

Nesbitt HW, Bancroft GM, Fyfe WS, Karkhanis SN, Nishijima A, Shigemitsu S (1981) Thermodynamic stability and kinetics of perovskite dissolution. Nature 289: $358-362$

NiU Y (2004) Bulk-rock major and trace element compositions of abyssal peridotites: implications for mantle melting, melt extraction and post-melting processes beneath mid-ocean ridges. J Petrol 45: 2423-2458

Parkinson IJ, Pearce J (1998) Peridotites from the Izu-Bonin-Mariana forearc (ODP Leg125): evidence for mantle melting and melt-mantle interaction in a suprasubduction zone setting. J Petrol 39: 1577-1618

Plašienka D, Grecula P, Putiš M, Kováč M, Hovorka D (1997) Evolution and structure of the Western Carpathians: an overview. In: Grecula P, Hovorka D, Putiš M (eds) Geological Evolution of the Western Carpathians. Miner Slov - Geocomplex, Bratislava, pp 1-24i

PutiRKa K (2008) Thermometers and barometers for volcanic systems. In: Putirka K, Tepley F (eds) Minerals, Inclusions and Volcanic Processes. Mineralogical Society of America Reviews in Mineralogy and Geochemistry 69: 61-120

Putiš M, Kotov AB, Uher P, Korikovsky SP, SaL'NiKova EB (2000) Triassic age of the Hrončok pre-orogenic Atype granite related to continental rifting: a new result of U-Pb isotope dating (W. Carpathians). Geol Carpath 51: 59-66

Putiš M, Gawlick HJ, Frisch W, Sulák M (2008) Cretaceous transformation from passive to active continental margin in the Western Carpathians as indicated by the sedimentary record in the Infratatric Unit. Int J Earth Sci (Geol Rundsch) 97: 799-819

Putiš M, Frank W, Plašienka D, Siman P, Sulák M, Biroň A (2009) Progradation of the Alpidic Central Western Carpathians orogenic wedge related to two subductions: constrained by ${ }^{40} \mathrm{Ar} /{ }^{39} \mathrm{Ar}$ ages of white micas. Geodin Acta 22: 31-56

Putiš M, Radvanec M, Hain M, Koller F, Koppa M, SnárSKA B (2011a) 3-D analysis of perovskite in serpentinite (Dobšiná quarry) by X-ray micro-tomography. In: OndReJKA M, Šarinová K (eds) Proceedings of the Petros Symposium. Comenius University Press, Bratislava, pp 33-37

Putiš M, Radvanec M, Sergeev S, Koller F, Michálek M, Snárska B, Koppa M, Šarinová K, Németh Z (2011b) Metamorphosed succession of cherty shales with basalt and diastrophic breccia in olistolith of the Meliatic Jurassic accretion wedge near Jaklovce (Slovakia), dated on zircon (U-Pb SIMS SHRIMP). Miner Slov 43: 1-18

Putiš M, Koller F, Uher P, Koppa M, Snárska B, Michálek M, Spišiak J (2012) Orthopyroxene breakdown into perovskite and andradite garnet: a result of harzburgite -fluid interaction in the mantle and subduction channel. $34^{\text {th }}$ International Geological Congress, Brisbane, Australia, electronic Abstracts

RADVANEC M (2009) P-T path of perovskite-clinopyroxenegrossular bearing fragments enclosed in meta-peridotite (Danková, Gemer area, Western Carpathians). $8^{\text {th }}$ International Eclogite Conference, Xining, China, Abstracts, $121-122$

Radvanec M, Sergeev S, Putiš M, Larionov A (2009a) REE-rich chromotawmawite and majoritic garnet (?) bearing pale spheric fragment enclosed in meta-peridotite (Gemer area, Western Carpathians): zircon dating of UHP metamorphism and long-lasting mantle convection. $8^{\text {th }}$ International Eclogite Conference, Xining, China, Abstracts, 118-120

Radvanec M, Konečný P, Ondrejka M, Putiš M, Uher P, Németh Z (2009b) The Gemeric granites as an indicator of the crustal extension above the Late-Variscan subduction zone and during the Early Alpine riftogenesis (Western Carpathians): an interpretation from the monazite and zircon ages dated by CHIME and SHRIMP methods. Miner Slov 41: 381-394

Scambelluri M, Fiebig J, Malaspina N, Müntener O, Pettke T (2004) Serpentinite subduction: implications for fluid processes and trace-element recycling. Int Geol Rev 46: 595-613

Scambelluri M, Hermann J, Morten L, Rampone E (2006) Melt- versus fluid-induced metasomatism in spinel to garnet wedge peridotites (Ulten Zone, Eastern Italian Alps): clues from trace element and $\mathrm{Li}$ abundance. Contrib Mineral Petrol 151: 372-394 
Seyler M, Toplis MJ, Lorand J-P, Luguet A, Cannat M (2001) Clinopyroxene microtextures reveal incompletely extracted melts in abyssal peridotites. Geology 29: 155-158

Stampfli GM (1996) The Intra-Alpine terrain: a Paleotethyan remnant in the Alpine Variscides. Eclogae Geol Helv 89: 13-42

Uher P, KodĚra P, Vaculovič T (2011) Perovskite from CaMg skarn-porphyry deposit Vysoká - Zlatno, Štiavnica stratovolcano, Slovakia. Miner Slov 43: 247-254

Uysal İ, Ersoy EY, Karsli O, Dilek Y, Sadiklar MB, Ottley ChJ, Tiepolo M, Meisel T (2012) Coexistence of abyssal and ultra-depleted SSZ type mantle peridotites in a Neo-Tethyan Ophiolite in SW Turkey: constraints from mineral composition, whole-rock geochemistry (major-trace-REE-PGE), and Re-Os isotope systematic. Lithos 132-133: 50-69

VozÁrová A, Šmelko M, Paderin I (2009) Permian single crystal U-Pb zircon age of the Rožňava Formation volcanites (Southern Gemeric Unit, Western Carpathians, Slovakia). Geol Carpath 60: 439-448

Whitney DL, Evans BW (2010) Abbreviations for names of rock-forming minerals. Amer Miner 95: 185-187

Zajzon N, Kristály F, SzakÁl S, Fehér B, VÁczi T, Pekker P (2010) Pyrophanite after perovskite from serpentinite at Perkupa, northern Hungary. Acta Mineral-Petrogr, Abstr Ser 6: 446 